\title{
PROTECCION CONSTITUCIONAL DEL DERECHO A LA INVIOLABILIDAD DEL DOMICILIO EN EL ÁMBITO CASTRENSE
}

\author{
CONSTITUTIONAL PROTECTION OF THE RIGHT TO INVIOLABILITY OF \\ THE HOME IN THE MILITARY SPHERE
}

\author{
GEMA GARCIA MARTINEZ*
}

SUMARIO: I. ALGUNAS CUESTIONES PREVIAS. II. EL DERECHO A LA INVIOLABILIDAD DEL DOMICILIO. III. CONCEPTO DE DOMICILIO. IV. RESIDENCIAS MILITARES. V. VIVIENDAS MILITARES. VI.CAMAROTES DE BUQUES, SUBMARINOS DE LA ARMADA Y AERONAVES MILITARES. VII. TIENDAS DE CAMPAÑA, CONTENEDORES O BARRACONES. VIII. ALOJAMIENTOS LOGÍSTICOS HABILITADOS PARA LA TROPA Y MARINERÍA. IX. A MODO DE CONCLUSIÓN. X. BIBLIOGRAFÍA.

SUMMARY: I. SOME PRELIMINARY QUESTIONS. II. HOME INVIOLABILITY RIGHT. III. DOMICILIE, CONCEPT. IV. MILITARY RESIDENCES. V. MILITARY HOUSING. VI. NAVY'S SHIP AND SUBMARINE CABINS, AND MILITARY AIRCRAFTS. VII. TENTS, CONTAINERS OR BARRACKS. VIII. LOGISTIC ACOMMODATION FOR THE ARMY AND NAVY STAFF. IX. CONCLUSIONS. X. BIBLIOGRAPHY.

Resumen: La especialidad de las misiones que constitucionalmente le han sido encomendadas a las Fuerzas Armadas y a sus miembros, así como la singularidad de los destinos del personal militar, con frecuentes cambios de localidad de manera forzosa, hacen que, de manera habitual, se vean obligados a residir fuera de su domicilio familiar. Es por este motivo, por el que en numerosas ocasiones los militares desarrollan su privacidad bien en cuartos habilitados en las propias unidades, centros u organismos militares, en residencias militares gestionadas por directores con empleo militar y dependientes del Ministerio de Defensa o en períodos de ejercicios, maniobras o misiones, dentro o fuera del territorio nacional, en tiendas de campaña, barracones, o buques. De esta manera, podemos observar, como se amplían considerablemente los lugares en los que los miembros de esta institución, desarrollan su vida privada, lo cual a su vez, genera problemas de determinación en torno a cuáles de estos lugares pueden incluirse en el concepto de domicilio constitucionalmente merecedor de protección, especialmente a los efectos de la realización de entradas y registros.

Abstract: Missions constitutionally entrusted to the Army and its personnel, a speciality in our law, as well as the uniqueness of its members destinations, with frequent town changes, voluntary or forced, forced them to live away from home. This situation makes them develop their privacy either in enabled rooms in their military units, centres or organisations or military residences managed by militar directors with military and depending on the Ministry of Defence, moreover, in p exercise, maneuver or mission periods, within or outside the national territory, in tents, barracks, or ships. This way we realize how their private life is taking place in a number of locations that is considerably expanding, generating problems to determine which among these places

\footnotetext{
* Capitán Auditor del Cuerpo Jurídico Militar. Oficial de la Asesoría Jurídica de la Fuerza de Acción Marítima (Armada Española). Abogada del Estado Habilitada. Máster EEES en Derechos Fundamentales especialista en Protección Jurisdiccional. Doctoranda de la Universidad de Jaén.
} 
can be included in the concept of domicilie that deserves constitutional protection, mainly for entering and searching procedures and its preparation.

Palabras clave: Derecho fundamental, Intimidad, Domicilio, Fuerzas Armadas. Keywords: Fundamental Right, Intimacy, Home, Armed Forces.

\section{Algunas cuestiones previas.}

El objetivo que nos marcamos mediante la elaboración de este estudio, no es otro que el de llevar a cabo una traslación al ámbito militar del conjunto de garantías constitucionalmente previstas para la inviolabilidad del domicilio. A su vez y aprovechando dicha traslación se pretende también reparar en la protección de la intimidad, que en el mismo ámbito se produce, a fin de determinar si es o no es posible sin las debidas adaptaciones a las especialidades propias de esta organización, desplegar las garantías referidas en el ámbito castrense, teniendo en cuenta que todo apunta a que estas especialidades son necesarias para el cumplimiento de las misiones que la Constitución y las leyes encomiendan a las Fuerzas Armadas y a los militares en su conjunto.

Partimos de la hipótesis de que, ciertamente, la condición militar no restringe en sí misma la atribución y el ejercicio de los derechos fundamentales que se reconocen al resto de los ciudadanos. Pero su estatuto resulta de una relación especial de sujeción, del que forman parte un conjunto de deberes cuyo cumplimiento modula el ejercicio de aquellos derechos esenciales, entre ellos la intimidad cuando el espacio en que ésta se desarrolla se localiza dentro de unidades, bases o acuartelamientos, dependencias militares en suma, sometidas al necesario control de los jefes de las unidades, que legalmente son los responsables de su disciplina y buen gobierno y cuya actuación sigue estando al servicio del cumplimiento de los fines que se asignan a la actuación de los Ejércitos.

Nos adentramos en un estudio, en el que si bien somos conscientes, no es novedoso, tampoco resulta ser una cuestión resuelta. Nos consta que en el día a día de los cuarteles aún suscita dudas, por ejemplo, la legitimación del mando militar como autoridad administrativa, ante la necesidad de efectuar una entrada y registro en dependencias bajo su mando y en aras a esa responsabilidad de mantener la disciplina a la que en renglones anteriores nos referíamos. Estas dudas traen causa de la inexistencia de una postura unánime y de la falta de consenso entre los juristas militares a la hora de delimitar qué dependencias castrenses son susceptibles de quedar incluidas en el marco de protección constitucional del derecho a la inviolabilidad del domicilio. Esta realidad, deja en el aire la respuesta a posibles conflictos de intereses tales como: ¿Cuándo debe primar el derecho fundamental frente al valor-disciplina?; ¿qué dependencias quedarían fuera de dichos márgenes de protección?; ante la misma ponderación, ¿cuándo cedería el derecho fundamental al valor-disciplina?. De ahí el interés en este estudio con el objetivo de delimitar el concepto y naturaleza de las distintas dependencias militares más destacadas y la vuelta a la vieja polémica de: ¿Está el mando militar legitimado para efectuar una entrada y registro en dependencias militares?.

La cuestión que nos planteamos no es baladí y además viene acompañada de la dificultad añadida de escasas referencias doctrinales sobre la materia, inexistentes pronunciamientos del Tribunal Constitucional aplicados al ámbito castrense; por ejemplo, respecto a la consideración de domicilio de los sollados de los buques militares

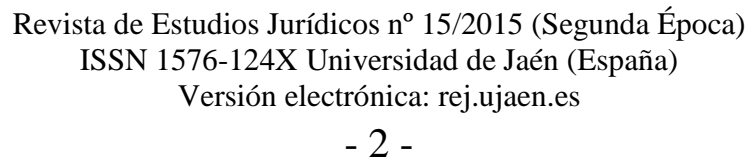


o de los submarinos de guerra; y la dificultad de acceso a las resoluciones de los tribunales militares, que son los que un última instancia arrojan algo de luz a nuestro planteamiento.

Nuestra conclusión final, habrá de traer causa de la exposición de los elementos delimitadores del concepto de domicilio inviolable, esto es, el objetivo, como uso o destino al ejercicio de la privacidad, y el subjetivo, consistente en la libre decisión del interesado en cuanto a establecer en un espacio determinado su ámbito de privacidad y la potestad que se deriva en cuanto a la exclusión de los demás.

Partimos también, de la hipótesis de que no puede sostenerse que en las dependencias militares se prediquen tales elementos con la misma intensidad, por la confluencia de aquellos intereses, vinculados necesariamente a la idea básica del servicio y por extensión al más amplio concepto de la defensa nacional.

Si bien pretendemos demostrar que en la medida en que en los espacios, inmuebles o muebles, ocupados por el personal militar o las pertenencias de éstos, se aprecie la existencia de un mínimo de intimidad protegible, ésta debe quedar garantizada en términos equiparables a los que se aplican al resto de los ciudadanos, efectuando la interpretación que resulte más favorable para la virtualidad del derecho fundamental afectado. Habrá de recaer nuestra atención pues, en las dependencias destinadas al descanso durante los actos del servicio, a los dormitorios comunes en determinadas unidades, a las residencias militares, viviendas militares, pabellones de cargo, tiendas de campaña, barracones, respecto de los que cabe distinguir entre la realización de aquellas revistas o inspecciones, a efectos de régimen interior acordadas por los jefes de las unidades, y los registros motivados por la sospecha de la comisión de algún delito.

En definitiva, va a constituir cuestión nuclear de nuestro trabajo, las singularidades que en el ámbito de las Fuerzas Armadas, se dan respecto a las intervenciones que supongan la afectación al derecho a la intimidad, en su vertiente de inviolabilidad domiciliaria y en concreto respecto de la entrada y registro que se realice en dependencias militares.

La especialidad de las misiones que constitucionalmente le han sido encomendadas a las Fuerzas Armadas y a los profesionales de las armas, así como las características de los destinos del personal militar, con continuos cambios de localidad de manera forzosa, hacen que en numerosas ocasiones, se vean obligados a residir fuera de su domicilio familiar, desarrollando su intimidad bien en cuartos habilitados en las propias unidades, en residencias militares gestionadas por directores con empleo militar y dependientes del Ministerio de Defensa, o, en períodos de ejercicios, maniobras o misiones, dentro o fuera del territorio nacional, en tiendas de campaña, barracones, o buques. Por este motivo, se amplían considerablemente los lugares en los que los militares pueden llegar a convivir y desarrollar su vida privada, circunstancias estas, que suscitan dudas desde el punto de vista de los derechos fundamentales, en torno a la determinación de cuáles de entre estos lugares pueden incluirse en el concepto de domicilio constitucionalmente merecedor de protección, a los efectos de la realización de entradas y registros y cuáles no.

En conclusión, mediante la elaboración de este trabajo, se pretende ahondar en el régimen jurídico del derecho a la inviolabilidad del domicilio en el ámbito castrense, con la finalidad de determinar si las misiones y las funciones que tienen encomendadas las Fuerzas Armadas, vía artículo 8 de la Constitución Española, precisa o no, de determinadas limitaciones en el ejercicio de tal derecho por parte de sus miembros, o si 
por el contrario, la regulación y el desarrollo del contenido del mismo, es compatible con las funciones del personal militar.

¿Constituye la condición de militar un motivo suficiente para que el personal militar, se vea restringido en el ejercicio de su derecho fundamental a la inviolabilidad del domicilio con sujeción a un régimen de protección diferente que al del resto de los ciudadanos?.

Mediante nuestro trabajo, nos adentramos en el estudio y la justificación de los límites al derecho fundamental a la intimidad e inviolabilidad del domicilio cuando tiene por titulares a los miembros de las Fuerzas Armadas, ${ }^{1}$ su eficacia, en lo que podríamos denominar siguiendo a Esquivias López-Cuervo, ${ }^{2}$ lugares militares, entendiendo éstos, en sentido amplio, y en una primera aproximación, como todas aquellas instalaciones, recintos, establecimientos militares, establecimientos en los que se desarrollen actividades militares o cualquier otro que aparezca definido como tal en la normativa específica, ${ }^{3}$ así como en la dificultad de mantener el adecuado equilibrio entre la condición de militar y la potencial afectación, con relevancia constitucional, que el desarrollo de esa actividad profesional pudiera presentar en este derecho fundamental del militar.

No obstante todo lo anterior, a la hora de dar respuesta a las cuestiones que hemos planteado, se hace precisa una pequeña introducción que facilite al lector un mayor entendimiento de la existencia de una serie de condicionantes personales de sujeción en el seno de ésta institución y de una serie de límites establecidos a los miembros de las Fuerzas Armadas que nos permite hablar de un estatuto personal o un régimen especial de derechos y libertades, específicos, respaldados por la Constitución y diferentes al del resto de los ciudadanos.

En ese sentido, y desde una perspectiva tradicional, al militar, se le ha visto como a un ciudadano diferente, como a una persona con un entrenamiento físico y mental excepcional, capaz de resistir ante situaciones muchas veces inimaginables para un ciudadano corriente.

Hoy día, se le sigue viendo como a un miembro de una organización presidida por la disciplina y subordinación, sujeto a estrictos códigos de valores ${ }^{4}$ y conductas, programas de adiestramiento específicos e incluso, por qué no, como a un funcionario de la Administración General del Estado, eso sí, pero con un estatus especial. ${ }^{5}$

\footnotetext{
${ }^{1}$ En adelante FAS.

2 Cfr.: ESQUiVIAS LÓPEZ-CUERVO, A; JOLY PALOMINO F. y MARTíN VICENTE M.: Comentarios a la Ley Disciplinaria Militar. Diario de Cádiz. Cádiz 1999.

${ }^{3}$ En adelante UCO,S.

${ }^{4}$ Cfr.: FERNÁNDEZ SEGADO, F.: «El perfil diferencial de la escala de valores de la Institución Militar». Revista de Estudios Políticos n ${ }^{\circ 51}$, mayo-junio 1986, pp. 79 y ss.

El propio Tribunal Constitucional se ha referido a este peculiar código de valores en el auto 446/1984, de 11 de julio, Fundamento Jurídico 6, al razonar que los bienes jurídicos protegidos por los delitos contra el honor militar: "Guardan relación directa con la peculiar naturaleza y singulares valores de la organización castrense, dentro de la que destaca la condición o status de militar, como particular manera de ser y actuar en pro de altos fines, que comporta la sujeción a un sistema normativo en que se imponen de forma muy significativa determinados valores".

${ }^{5}$ La STC 60/91 de 14 de marzo entendió que: “No es aceptable la visión de lo castrense como un mundo aparte, y del derecho militar como el ordenamiento interno de una institución separada que configura una sociedad distinta, perfecta y completa”.
}

$$
\begin{gathered}
\text { Revista de Estudios Jurídicos no 15/2015 (Segunda Época) } \\
\text { ISSN 1576-124X Universidad de Jaén (España) } \\
\text { Versión electrónica: rej.ujaen.es }
\end{gathered}
$$


Como diría Herrero De Miñón en el debate parlamentario del artículo 8 de la Constitución, en pleno proceso constituyente: ${ }^{6}$ "Las Fuerzas Armadas son Administración Pública, pero son también algo más”, ello explicaría por qué, entre otras muchas cosas, la jefatura suprema de esas Fuerzas Armadas se atribuye a quien es cabeza del Estado y garante de su Constitución, esto es, al Rey.

De entre sus cometidos se encontrarán el acatamiento y lealtad al poder político derivado de la soberanía nacional ${ }^{7}$ y el bien común; bien común que determina la finalidad de la institución y tiene que prevalecer sobre los intereses individuales y subjetivos de sus miembros, configurándose de esta forma su estatus institucional específico. $^{8}$

Siguiendo la doctrina del Tribunal Europeo de Derechos Humanos el estatuto jurídico de los militares se inserta en el marco de las relaciones de sujeción especial, con mayor intensidad aún que el resto de los servidores públicos.

En atención a razones como la extraordinaria relevancia de las potestades que le encomienda la Constitución y la Ley de la Defensa Nacional, así como su derecho a portar armas, los militares deben estar sometidos a una restricción de sus derechos, que se justifica por la necesidad de proteger ciertos fines o intereses, constitucionalmente reconocidos, aunque eso sí, con las debidas garantías. ${ }^{9}$

El artículo 8 de la Constitución Española, ${ }^{10}$ notablemente influido en su redacción por la Ley Orgánica del Estado de 1967, ${ }^{11}$ establece las misiones de las Fuerzas Armadas: "Garantizar la soberanía e independencia de España, defender su integridad territorial y el ordenamiento constitucional”, que no son precisamente marginales dentro de la actividad del Estado, sino, antes al contrario, se erigen como, no solo la garantía de la propia existencia y supervivencia del mismo, sino también la propia razón de ser de la institución militar. ${ }^{12}$

Ahora bien, estas limitaciones se deben establecer por ley, justificarse en la protección de un derecho, bien o interés constitucional, ser adecuadas y proporcionadas para garantizar dicha protección y respetar el contenido esencial del derecho regulado.

La neutralidad, la unidad, la disciplina y la legislación especial que tiene como principales destinatarios a quienes ostentan el monopolio del ejercicio de la fuerza armada del Estado, justifica a su vez la existencia de leyes penales especiales, disciplinarias particulares, así como una jurisdicción penal y un régimen disciplinario

\footnotetext{
${ }^{6}$ Véase. Herrero de Miñón, M. en Diario de Sesiones del Congreso de los Diputados (Comisión de Asuntos Constitucionales) de 16 de mayo 1978.

${ }^{7}$ Vide. Artículo 1.2 Constitución Española: “La soberanía nacional reside en el pueblo español, del que emanan los poderes del Estado".

${ }^{8}$ Cfr.: Trillo-Figueroa y Martínez-Conde, F.: «Las Fuerzas Armadas en la Constitución Española», Revista Española de Derecho Militar, n 38, 1979, pp. 93.

${ }^{9}$ Vid. STEDH de 8 de junio de 1976, caso "Engel y otros" contra el Estado Holandés y STEDH de 24 de febrero de 1998, asunto "Larissis y otros” contra Grecia.

${ }^{10}$ En adelante, CE.

${ }^{11}$ El artículo 37 de la Ley Orgánica del Estado de 1967, que era la norma de apertura del Título VI de la misma, se dedicaba a las Fuerzas Armadas y decía literalmente que: “Las Fuerzas Armadas de la Nación, constituidas por los Ejércitos de Tierra, Mar y Aire y las Fuerzas de Orden Público, garantizan la unidad $e$ independencia de la Patria, la integridad de sus territorios, la seguridad nacional y la defensa del orden institucional”.

${ }^{12}$ Cfr.: Trillo- Figueroa Martínez Conde, F.: «Las Fuerzas Armadas en la Constitución Española (Esbozo de una Constitución Institucional)», Revista de Estudios Políticos n¹2, 1979, pp. 116; Fernández Segado, F.: «La posición constitucional de las Fuerzas Armadas». Revista Española de Derecho Militar, $\mathrm{n}^{\circ}$ 67.1996, pp. 26.
} 
militar. A ello se refiere Casado Burbano, cuando indica, que son cuatro los principios en los que se basan la restricción de los derechos de los militares: "Supremacía civil, neutralidad política, rigurosa disciplina y unidad". ${ }^{13}$

Afirma Querol y Durán ${ }^{14}$ que donde quiera que hayan existido Fuerzas Armadas regulares y organizadas, han funcionado, más o menos embrionariamente, las leyes de la justicia de carácter militar específico.

En parecida línea, Casado Burbano ${ }^{15}$ recuerda que desde tiempos remotos puede apreciarse cómo el núcleo esencial de bienes y valores protegidos por normas penales están en relación directa con la eficacia de las Fuerzas Armadas en el combate.

No obstante, como ya indicara el Tribunal de Estrasburgo, la condición de ciudadano no puede detenerse a la puerta de los cuarteles, por lo que habrá que encontrar una solución equitativa reconociendo de ésta manera, que las limitaciones a los derechos fundamentales, van a ser inevitables. ${ }^{16}$

Tradicionalmente, el estatuto jurídico de los empleados públicos se ha visto sometido a una serie de especialidades y restricciones que, desde el punto de vista doctrinal, han sido consideradas como constitutivas de una relación de sujeción especial. $^{17}$

Ello no significa que las peculiaridades de la vida militar desvirtúen o alteren la eficacia de los derechos fundamentales de los que son titulares, sino que las limitaciones a los mismos sólo son "admisibles en la medida en que resulten estrictamente indispensables para el cumplimiento de la misión o función derivada de aquella situación especial". ${ }^{18}$

Hablamos de restricciones, no de exclusiones de titularidad, tal y como señala el profesor Embid, ${ }^{19}$ ya que debemos tener presente que no es que los derechos no sean ilimitados, como es reiterada doctrina de nuestro Alto Tribunal, ${ }^{20}$ sino que se han

${ }^{13}$ Cfr.: Casado Burbano, P.: Iniciación al derecho constitucional militar. EDERSA. Madrid. 1986, pp. 22.

${ }^{14}$ Cfr.: Querol y Durán, F.: Principios de Derecho Militar Español (Vol. I). Editorial Naval. Madrid. 1948, pp. 92.

${ }^{15}$ Cfr.: Casado Burbano, P.: «Visión Histórica del Derecho Penal Militar Español. Comentario al Capítulo I del Código penal Militar», en AA.VV. (coord. José Luis Rodríguez Villasante), Comentarios al Código Penal Militar. Editorial Civitas. Madrid. 1988, pp. 29 y ss.

${ }^{16}$ Vid. STEDH de 19 de diciembre de 1994 asunto Vereinigung DemoKratischer Soldaten Osterreichs y Gubi contra Austria; STEDH de 25 de noviembre de 1997, asunto Grigoriades contra Grecia. En el mismo sentido STEDH de 21 de octubre de 1999 caso Janouski contra Polonia.

${ }^{17}$ Cfr.: García de Enterría, E y Fernández, Tomás-Ramón.: Curso de Derecho Administrativo (Tomo I). Editorial Cívitas. Madrid. 1990, pp. 443 y García de Enterría, E y Fernández, Tomás-Ramón.: Curso de Derecho Administrativo (Tomo II)..., op, cit, pp. 21. Puede consultarse también la STC 114/1987, de 6 de julio, FJ 4, según el cual: “(...) El ordenamiento puede anudar legítimamente en ciertos supuestos determinadas consecuencias gravosas al incumplimiento de deberes jurídicos explícitos de trascendencia pública, genéricamente descritos como deber de observancia de buena conducta, cuando así lo exija razonablemente el interés público que con ello pretende protegerse. Así ocurre sobre todo en el ámbito de las relaciones de especial sujeción, cuando aquellas exigencias se vinculen directamente a garantizar la específica disciplina, cohesión interna o respetabilidad pública de las instituciones en que se desenvuelven dichas relaciones”. STC que trae causa del recurso de amparo interpuesto por vulneración del artículo 14 CE, contra la STS Sala 5a, que confirmaba la denegación de la pensión de jubilación, retiro o haberes pasivos, a un expulsado de la Legión por tráfico de estupefacientes.

${ }^{18}$ Vid. STC 235/1998, de 14 de diciembre, FJ 5 ${ }^{\circ}$.

${ }^{19}$ Cfr.: Embid Irujo, A.: La fidelidad de los funcionarios a la Constitución (un estudio de los Derechos alemán y español). INAP. Madrid. 1987, pp. 151 y ss.

${ }^{20}$ Vid. STC 2/1982, de 29 de enero: "No existen derechos ilimitados."

$$
\begin{gathered}
\text { Revista de Estudios Jurídicos no 15/2015 (Segunda Época) } \\
\text { ISSN 1576-124X Universidad de Jaén (España) } \\
\text { Versión electrónica: rej.ujaen.es }
\end{gathered}
$$


establecido limitaciones de ejercicio tanto en la CE como en la legislación que la desarrolla y que, llevado al extremo, no afecta a ninguna otra categoría de ciudadanos más que a los militares.

La entrada en las FAS supone un sometimiento voluntario a un régimen más específico y restrictivo en materia de derechos, respecto de cualquier ciudadano, pero eso no significa su renuncia. ${ }^{21}$ Ésta ha sido precisamente la postura de nuestro Tribunal Constitucional, que tradicionalmente viene admitiendo la imposición de límites a determinados colectivos, entre los que se encuentran los funcionarios o militares, pero siempre que estén justificados, sean proporcionales y necesarios para proteger otros derechos también reconocidos en el texto constitucional o resulten estrictamente indispensables para el cumplimiento de las misiones encomendadas. ${ }^{22}$

Admitida la naturaleza jurídica del militar como parte integrante de esa Administración Pública, nuestra postura acompaña la opinión, no solamente de gran parte de la doctrina, ${ }^{23}$ sino también de nuestro máximo intérprete de la $\mathrm{CE},{ }^{24}$ que considera el estatuto jurídico del militar una manifestación más de esa relación de especial sujeción a la que se encuentran sometidos no sólo los funcionarios, ${ }^{25}$ sino también, entre otros colectivos, los militares, por la sencilla razón de las misiones que tienen encomendadas nuestras FAS, según el reiterado artículo $8 \mathrm{CE}$ que, en definitiva, determinan la necesidad de que la ley regule sus derechos y libertades, modulándolos en ciertos casos, en atención a las especiales características del servicio y las reglas de disciplina y jerarquía.

El considerar el estatus del militar un estatus especial, tiene gran repercusión constitucional, ya que ello supone la afección de la mayor parte de los derechos fundamentales de un amplio grupo de ciudadanos y ha sido materia objeto de interés y estudio por parte de la doctrina como vemos a continuación.

Para el profesor Mariano López Benítez ${ }^{26}$ el militar está indiscutiblemente inserto en una relación de sujeción especial y carece de sentido plantear cuestión alguna al respecto, si bien, esa circunstancia implica unos efectos sobre la libertad y los derechos fundamentales. La diversa intensidad de las restricciones a que se someten están directamente entroncadas con el fin típico que les ha asignado el ordenamiento jurídico.

\footnotetext{
${ }^{21}$ Vid. STS Sala 5a, de 8 de junio de 1994.

${ }^{22}$ Cfr.: López Benítez, M.: Naturaleza y presupuestos constitucionales de las relaciones de especial sujeción, prólogo de Luis Cosculluela Montaner. Editorial Cívitas. Madrid, 1994, pp. 264.; Sánchez Morón, M.: Derecho de la Función Pública. Editorial Tecnos. Madrid. 1997, pp. 218. Vide. STC 11/81 y STC 235/1998, de 14 de diciembre, FJ 5. STC 24/1999, de 8 de marzo y STC 70/1981 FJ 15․ Todas ellas relativas a la relación de especial sujeción del personal militar.

${ }^{23}$ Cfr.: Gallego Anabitarte, A.: «Las relaciones especiales de sujeción y el principio de legalidad de la Administración. Contribución a la teoría del Estado de Derecho», Revista de Administración Pública, $\mathrm{n}^{\circ}$ 34, año XII, enero-abril 1961 (reimpresión octubre 1972). Instituto de Estudios Políticos. Madrid, pp. 2526.

${ }^{24}$ Vid. STC 2/1987, de 21 de enero; STC 114/1987, de 6 de julio, FJ 5; STC 371/1993, de 13 de diciembre, FJ 4; SSTC 120/1990 y 137/1990; STC 129/1995, de 11 de septiembre.

${ }^{25}$ Vide. STC 93/1984, de 16 de octubre, FJ 3: “(...) La sala no estima que la regulación por la LJCA de un procedimiento especial en materia de personal sea contraria al artículo 14 de la CE, por cuanto no puede calificarse de discriminatoria ya que tiene un fundamento objetivo y razonable, pues en efecto, dada la existencia de una relación de supremacía especial entre la Administración y los funcionario (...)".

${ }^{26}$ Cfr.: López Benítez M.: Naturaleza y presupuestos constitucionales de las relaciones de especial sujeción,...op, cit, pp 497- 498.
}

Revista de Estudios Jurídicos nº 15/2015 (Segunda Época)

ISSN 1576-124X Universidad de Jaén (España)

Versión electrónica: rej.ujaen.es 
El profesor Antonio Embid ${ }^{27}$ justifica ese estatuto especial en la posibilidad constitucional de que los derechos fundamentales de estos ciudadanos pueden sufrir más restricciones que los del resto. Límites que pueden ser distintos según la función cumplida y el cuerpo al que se pertenece, ya que no existe una restricción generalizada y homogénea para todos los funcionarios, por el hecho de gozar de ésta determinación. Por tanto, la naturaleza de la relación funcionarial obra como cláusula general de limitación pero no de manera uniforme.

Peñarrubia $\mathrm{Iza}^{28}$ entiende la función militar desde, el punto de vista objetivo, como aquella prestada por el Estado para la defensa nacional, por medio de la organización militar, mientras que desde el punto de vista subjetivo, la entiende como el conjunto de personas sometidas a la disciplina militar que prestan sus servicios de manera voluntaria en esa organización militar.

Fernández Rodera ${ }^{29}$ opina que no se trata de negar al militar el ejercicio de sus derechos fundamentales, sino de acomodarlo a la estructura de las Fuerzas Armadas.

Trillo-Figueroa ${ }^{30}$ considera que el estatus del militar es un estatus amplio e instrumental y lo entiende como "el condensador de la posición jurídica especial que corresponde permanentemente al militar en derecho público".

Finalmente, Garrido Falla ${ }^{31}$ manifiesta que el estatuto del militar contiene un solo fundamento que abarca cuestiones no homogéneas. Su estatuto jurídico tiene su expresión legal en las Reales Ordenanzas para las Fuerzas Armadas y en los principios de disciplina y jerarquía.

\section{El derecho a la inviolabilidad del domicilio.}

Nos adentramos en el fondo del asunto en nuestro estudio, abordando en primer lugar la siguiente cuestión: debe destacarse respecto de la inviolabilidad de domicilio que "no tutela tanto el bien domicilio in se y per se considerado, como la garantía personal del sujeto que es titular del mismo", si bien responde a la necesidad "de preservar" la esfera de intimidad y los comportamientos que en ella se llevan a cabo, como "contenido y manifestación principal y básico de la denominada libertad civil".

En efecto, para el profesor González-Trevijano, el derecho a la inviolabilidad del domicilio pretende amparar ampliamente una esfera particular y espacialmente definida -el domicilio-, dentro de la cual se pueden desarrollar, sin interferencias externas y con plena intimidad y reserva, las actividades privadas del ciudadano. ${ }^{32}$

El hogar de todo individuo es inviolable, para que pueda permitirse alguna interferencia, ésta no debe ser arbitraria. Más no solo es objeto de protección el espacio

\footnotetext{
${ }^{27}$ Cfr.: Embid Irujo, A.: La fidelidad de los funcionarios a la Constitución..., op, cit, pp. 68.

${ }^{28}$ Cfr.: Peñarrubia Iza, J.M.: Presupuestos constitucionales de la función pública. Centro de Estudios Políticos y Constitucionales. Madrid. 2000, pp. 50-51.

${ }^{29}$ Cfr.: Gómez Martínez, R.: Derechos fundamentales y condición militar. Editorial Civitas. Navarra. 2010, pp. 91 cita a Fernández Rodera, J.A.: «Límites al ejercicio de derechos cívicos en el ámbito castrense», Revista del Ejército, no 525, octubre 1983, pp.64.

${ }^{30}$ Cfr.: Trillo- Figueroa Martínez Conde, F.: «Las Fuerzas Armadas en la Constitución Española»,... op, cit, pp. 131-132.

${ }^{31}$ Cfr.: Gómez Martínez, R.: Derechos fundamentales y condición militar,... op, cit, pp. 89 cita a Garrido Falla, F.: Comentarios a la Constitución. Editorial Cívitas. Madrid. 1985, pp. 141-143.

${ }^{32}$ Cfr.: González- Trevijano, P.J.: La inviolabilidad del domicilio. Temas clave de la Constitución Española. Editorial Tecnos. Madrid. 1992, pp. 27 y ss..
} 
físico en sí mismo considerado, sino lo que hay de emanación de la persona y de esfera privada en ella. ${ }^{33}$

La inviolabilidad del domicilio se define como una prohibición genérica dirigida a terceros, ya sean particulares, o poderes públicos y al mismo propietario del domicilio para que respeten el círculo material y el sentido espiritual que encierra el concepto de domicilio.

La confirmación del derecho se manifiesta en la ausencia de actos externos que pongan en cuestión lo que se pretende con un reconocimiento constitucional de tal índole. $^{34}$

En definitiva, la inviolabilidad del domicilio es un derecho que pretende garantizar el ámbito de privacidad de la persona dentro del espacio limitado que ésta elija y que tiene que caracterizarse, precisamente, por quedar exento o inmune a las agresiones o invasiones exteriores de otras personas o de la autoridad. ${ }^{35}$

Siguiendo al profesor Gimeno Sendra, podemos definir el derecho a la inviolabilidad del domicilio, como el derecho a que nadie entre en el domicilio en contra de la voluntad de su titular o sin previa autorización judicial, salvo en caso de flagrante delito. ${ }^{36}$

El derecho fundamental que analizamos es un derecho de la personalidad que impide la entrada y registro a un domicilio sin el consentimiento de su titular y sin previa autorización judicial, salvo en determinados supuestos excepcionales contemplados por la ley.

El artículo 18.1 CE indica literalmente que: "El domicilio es inviolable. Ninguna entrada o registro podrá hacerse sin consentimiento del titular o resolución judicial salvo en caso de flagrante delito".

La inviolabilidad del domicilio comporta que la entrada al mismo solo es lícita en los casos previstos en la CE y en las leyes; esto es, consentimiento del titular, flagrante delito, ${ }^{37}$ autorización judicial, investigación de delitos terroristas ${ }^{38}$ y en los

\footnotetext{
${ }^{33}$ Cfr.: Figueroa Navarro, M.C.: Entrada y registro en domicilio. Tecnos. Madrid. 1994, pp. 12 ; Véase también Matía Portilla, F.J.: El derecho fundamental a la inviolabilidad del domicilio. McGraw-Hill. Madrid. 1997, pp.3.

${ }^{34}$ Cfr.: Alonso de Antonio, A.L.: El derecho a la inviolabilidad domiciliaria en la Constitución española de 1978. Editorial Colex. Madrid. 1993, pp. 72 .

${ }^{35}$ Cfr.: Figueroa Navarro, M.C.: Entrada y registro en domicilio.., op, cit, pp. 9.

${ }^{36}$ Cfr.: Gimeno Sendra,V.: Los Derechos Fundamentales y su Protección Jurisdiccional. Editorial Colex. Madrid. 2007, pp.157.

${ }^{37}$ Véase Sentencia TS núm. 922/2010 de 28 octubre. En el mismo sentido, la STS 716/2005, de 6 de junio, examina los supuestos que deben de concurrir para apreciar una situación de delito flagrante, indicando los siguientes:
}

1. Inmediatez, es decir que la acción delictiva se esté desarrollando o se acabe de realizar.

2. Relación directa del delincuente con el objeto, instrumentos o efectos del delito.

3. Percepción directa, no meramente presuntiva, de la situación delictiva.

4. Necesidad urgente de la intervención para evitar la consumación o agotamiento del delito, o la desaparición de los efectos del mismo.

Se equipara pues, la flagrancia a lo evidente, lo manifiesto y en relación con el delito, se estima delito flagrante, aquél que encierra en sí la prueba de su realización por existir una percepción sensorial directa del hecho delictivo. La STC 341/1993, de 18 de noviembre, identifica la flagrancia con la situación en la que la comisión de un delito se percibe con evidencia y por lo tanto con la imagen en la que un delincuente es sorprendido y visto directamente, en el momento de delinquir o en circunstancias inmediatas a su perpetración, siendo precisamente esta situación excepcional, que debe interpretarse restrictivamente como recuerda la STC de 31 de enero de 1994, la que permite la detención inmediata de la persona y lo que es más importante, permite la entrada y registro de domicilio sin mandamiento judicial y sin consentimiento del titular como aparece en el artículo 18.2 de la Constitución.

\author{
Revista de Estudios Jurídicos nº 15/2015 (Segunda Época) \\ ISSN 1576-124X Universidad de Jaén (España) \\ Versión electrónica: rej.ujaen.es
}


casos de estado de necesidad; ${ }^{39}$ consecuentemente, el domicilio así entendido deberá resultar inmune a cualquier tipo de invasión o agresión exterior de otras personas, incluida la autoridad pública, salvo en tales supuestos.

Se trata de un derecho de inequívoco significado personalista, derivado de la dignidad de la persona, que implica la existencia de un ámbito propio y reservado frente a la acción y conocimiento de los demás, necesario según las pautas de nuestra cultura para mantener una calidad mínima de vida humana. ${ }^{40}$

Para nuestro Tribunal Constitucional, ${ }^{41}$ el ámbito o espacio físico en el que se desarrolla gran parte de la actividad íntima de la persona es el domicilio, entendido como el espacio limitado que la propia persona elige para ejercer su libertad más íntima, libre de toda sujeción a los usos y convenciones sociales, ${ }^{42}$ es decir, en una acepción más amplia que la que proporciona el artículo 40 del Código Civil, como punto de localización de una persona o lugar del ejercicio por ésta de sus derechos y obligaciones.

Paralelamente, hemos de aludir al derecho a la intimidad personal que consagra el apartado 1 del artículo 18 de la CE, porque la inviolabilidad del domicilio está en más estrecha conexión con la vida privada, mientras que la tutela de la intimidad constituye una esfera más íntima y privada de las personas ${ }^{43}$ y que es definida, siguiendo a Moreno Catena ${ }^{44}$ como: "El concepto de carácter material mediante el cual se designa el área que una persona designa para sí, apartándola del conocimiento de terceros, siendo por naturaleza de carácter fluctuante”.

Para la profesora Navas Sánchez, la intimidad supone: "La preservación de un ámbito de cuestiones relacionadas con la esfera íntima del individuo frente a la intromisión ajena $o$, dicho de otro modo, la inexistencia de un ámbito propio y reservado frente a la actuación y el conocimiento de los demás, necesario, según las pautas de nuestra cultura, para mantener una calidad mínima de la vida humana". ${ }^{45}$

El concepto de intimidad no suele ser definido ni concretado por la legislación que debe protegerlo, de tal manera que el propio Tribunal Constitucional ha considerado que se trata de un concepto esencialmente abierto y no susceptible de una definición exhaustiva. ${ }^{46}$

El Tribunal Europeo de Derechos Humanos ${ }^{47}$ defiende una concepción esencialmente amplia del derecho a la intimidad. El caso más importante al respecto, lo

\footnotetext{
${ }^{38}$ Vide. Artículo 55.2 CE.

${ }^{39}$ La Ley Orgánica 4/1981, de 1 de junio reguladora de los estados de alarma, excepción y sitio, (BOE núm. 134/1981, de 5 de junio) en su artículo 17 autoriza a la autoridad gubernativa, con aprobación del Congreso, a intervenir las comunicaciones cuando resulte necesario para el esclarecimiento de los hechos delictivos o para el mantenimiento del orden público, debiendo comunicar la intervención al juez competente. Véase artículo 17 y artículo $18 \mathrm{CE}$.

${ }^{40}$ Vide. STC 23/ 1988 de 2 de diciembre.

${ }^{41}$ En adelante TC.

${ }^{42}$ Véase SSTC 22/1984 y 10/2002 de 17 de febrero.

${ }^{43}$ Cfr.: González-Trevijano, P.J., La inviolabilidad del domicilio...op, cit. pp 63-64.

${ }^{44}$ Cfr.: Moreno Catena, V.: «Garantía de los derechos fundamentales en la investigación penal». Revista del Poder Judicial. Justicia Penal. Núm. Especial II, marzo 1987.

${ }^{45}$ Cfr.: Navas Sánchez, M.M.: ¿Inviolabilidad o intimidad domiciliaria?. A propósito de la jurisprudencia constitucional sobre el derecho fundamental a la inviolabilidad del domicilio. Revista de Derecho Político $\mathrm{n}^{\circ}$ 81, mayo- agosto. UNED. 2011, pp. 192.

${ }^{46}$ Véase STC 110/1984, de 26 de noviembre.

${ }^{47}$ En adelante TEDH.
}

Revista de Estudios Jurídicos nº 15/2015 (Segunda Época)

ISSN 1576-124X Universidad de Jaén (España)

Versión electrónica: rej.ujaen.es 
constituye la sentencia de 16 de diciembre de 1992, caso Niemietz c. Alemania, en el que si bien el Tribunal no considera ni posible ni necesario ofrecer una definición exhaustiva de la noción de vida privada del artículo 8.1 del Convenio Europeo de Derechos Humanos $^{48}$ (artículo con el que más se puede identificar el derecho a la intimidad que protege el artículo 18.1 de nuestra Constitución), sin embargo considera que sería demasiado restrictivo reducir su ámbito al círculo interior al que el individuo desarrolla su propia vida personal.

En este sentido el TEDH afirma que: "El respeto de la vida privada debe, también, englobar hasta cierto punto el derecho a establecer y desarrollar relaciones con otros seres humanos".

Esta concepción, que trasciende a lo meramente individual, supone que, el respeto a la vida privada, frente a cualquier intromisión ajena, engloba actividades como las relativas a la vida e identidad sexuales, la integridad física y moral, ${ }^{49}$ la confidencialidad de datos sobre la salud, ${ }^{50}$ la elección del nombre propio, ${ }^{51}$ la garantía frente al almacenamiento, registro y comunicación de datos personales, ${ }^{52}$ o la protección frente a incisiones nocivas y molestas de ruidos y olores en los espacios donde la persona desarrolla su vida privada. ${ }^{53}$

Sin embargo, el Tribunal Europeo de Derechos Humanos ha establecido algunos límites en relación con el alcance del objeto de la vida privada, que ha de ser entendida como tal siempre que con ello se muestre la existencia de "un vínculo directo $e$ inmediato entre las medidas buscadas por el demandante y su vida privada y familiar " 54 o dicho de otra forma, la protección dispensada por el artículo 8.1 del Convenio Europeo de Derechos Humanos no se extiende a cualquier manifestación de la libre disposición individual sobre la propia vida, sino sólo a aquéllas que presenten un vínculo directo e inmediato sobre la vida privada de la persona.

Con el derecho fundamental que analizamos, se protege la inviolabilidad de la esfera de mayor privacidad del individuo, que es su domicilio, tratándose, en palabras de la jurisprudencia de la Sala Segunda del Tribunal Supremo, de: "Un derecho fundamental del ciudadano, cuya restricción, en cuanto supone una invasión de la zona de intimidad privada protegida por aquél, constituye un serio ataque a esferas de privacidad, que sólo puede ser acordado por resolución judicial”. ${ }^{55}$

Nos encontramos, pues, ante un derecho fundamental protegido frente a invasiones tanto de particulares, como de los poderes públicos, incluidos los agentes policiales, como señala De Urbano, ${ }^{56}$ ya que constituye una manifestación de la protección constitucional de la vida privada y de su intimidad personal, en el sentido dado por la propia jurisprudencia constitucional. ${ }^{57}$

\footnotetext{
${ }^{48}$ En adelante CEDH.

${ }^{49}$ Vide. STEDH de 26 de marzo de 1985, caso $X$ e $Y$ contra Países Bajos.

${ }^{50}$ Vide. STEDH de 25 de febrero de 1997, caso $Z$ contra Finlandia.

${ }^{51}$ Vide. STEDH de 22 de febrero de 1994, caso Burghatz contra Suiza.

52 Vide. STEDH de 4 de mayo de 2000, caso Rotaru contra Rumania.

${ }^{53}$ Vide. STEDH de 9 de diciembre de 1994, caso López Ostra contra España.

${ }^{54}$ Vide. STEDH de 24 de febrero de 1998, caso Botta contra Italia.

${ }^{55}$ Vid. SSTS de 18 de julio de 2005 y 17 de julio de 2006.

${ }^{56}$ Cfr.: Urbano Castrillo, E. y Torres Morato, M.A.: La prueba ilícita penal: estudio jurisprudencial, $3^{\circ}$ edición. Editorial Thomson. Pamplona. 2003, pp. 173.

${ }^{57}$ Véase STC 110/1984, de 26 de noviembre (Ponente Latorre Segura) y STC 22/84, de 17 de febrero (Ponente Díez-Picazo y Ponce de León), FJ 50: "El art. 18.2 CE contiene dos reglas distintas: una tiene carácter genérico o principal, mientras la otra supone una aplicación concreta de la primera y su contenido es por ello más reducido. La regla $1 .^{a}$ define la inviolabilidad del domicilio, que constituye un
} 
No obstante lo anterior, también es cierto que nos hallamos ante un derecho fundamental que no gozará del carácter de absoluto, sino que puede ser objeto de restricciones o limitaciones por parte del legislador, ${ }^{58}$ ahora bien, respetando siempre su contenido esencial. El derecho a la intimidad e inviolabilidad del domicilio, ha sido reconocido en la Carta Europea de Derechos fundamentales, cuyo artículo 7 dispone que: "Toda persona tiene derecho al respeto de su vida privada y familiar, de su domicilio y de sus comunicaciones" 59 y en el Convenio Europeo de Derechos Humanos, ratificado por España el 26 de septiembre de $1979,{ }^{60}$ en su artículo 8. ${ }^{\circ}$, donde se estableció que:

1. Toda persona tiene derecho al respeto a su vida privada y familiar, de su domicilio y de su correspondencia.

2. No podrá haber injerencia de la autoridad pública en este derecho, sino en tanto en cuanto esta injerencia esté prevista por la ley y constituya una medida que, en una sociedad democrática, sea necesaria para la seguridad nacional, la seguridad pública, el bienestar económico del país, la defensa del orden y la prevención del delito, la protección de la salud o de la moral, la protección de los derechos y libertades de los demás.

En igual sentido, y dentro de la comunidad internacional, el derecho ha tenido un amplio reconocimiento siendo uno de los derechos del individuo digno de ser protegido de la ilegalidad o de la arbitrariedad; y así se ha visto plasmado en el artículo 12 de la Declaración Universal de Derechos Humanos de 10 de diciembre de $1948^{61}$; y

auténtico derecho fundamental de la persona, establecido, según hemos dicho, para garantizar el ámbito de privacidad de ésta, dentro del espacio limitado que la propia persona elige y que tiene que caracterizarse precisamente por quedar exento o inmune a las invasiones o agresiones exteriores, de otras personas o de la autoridad pública. Como se ha dicho acertadamente, el domicilio inviolable es un espacio en el cual el individuo vive sin estar sujeto necesariamente a los usos y convenciones sociales y ejerce su libertad más íntima. Por ello, a través de este derecho no sólo es objeto de protección el espacio físico en sí mismo considerado, sino lo que en él hay de emanación de la persona y de esfera privada de ella. Interpretada en este sentido, la regla de la inviolabilidad del domicilio es de contenido amplio e impone una extensa serie de garantías y de facultades, en las que se comprenden las de vedar toda clase de invasiones incluidas las que puedan realizarse sin penetración directa por medio de aparatos mecánicos, electrónicos u otros análogos. La regla 2. ${ }^{a}$ establece un doble condicionamiento a la entrada y al registro, que consiste en el consentimiento del titular o en la resolución judicial. La interdicción fundamental de este precepto es la del registro domiciliar, entendido como inquisición o pesquisa, para lo cual la entrada no es más que un trámite de carácter instrumental. Contempladas desde esta perspectiva las cosas, puede extraerse la conclusión de que en toda actividad de ejecución de sentencias o decisiones llevada a cabo por los órganos públicos, en que se produce, bien que necesariamente, el ingreso de los órganos ejecutores en un domicilio privado, se realiza en mayor o menor medida una inquisición de éste. De la facultad que el titular del derecho sobre el domicilio tiene de impedir la entrada en él es consecuencia que la resolución judicial o la resolución administrativa que ordenan una ejecución que sólo puede llevarse a cabo ingresando en un domicilio privado, por sí solas no conllevan el mandato y la autorización del ingreso, de suerte que cuando éste es negado por el titular debe obtenerse una nueva resolución judicial que autorice la entrada y las actividades que una vez dentro del domicilio pueden ser realizadas”.

${ }^{58}$ Vid. STC núm. 11/1981, de 08 de abril (Ponente Díez-Picazo y Ponce de León).

${ }^{59}$ Vide. DOUE núm. 83, de 30 de marzo de 2010.

${ }^{60}$ Ese derecho se encuentra también reconocido en el ámbito de la UE, en el artículo 7 de la Carta de Derechos Fundamentales de la Unión Europea. Art. 7: “Toda persona tiene derecho al respeto de su vida privada y familiar, de su domicilio y sus comunicaciones”.

${ }^{61}$ Art. 12 de la Declaración Universal de Derechos Humanos: "Nadie será objeto de injerencias arbitrarias en su vida privada, su familia, su domicilio o su correspondencia”.

\section{Revista de Estudios Jurídicos nº 15/2015 (Segunda Época) \\ ISSN 1576-124X Universidad de Jaén (España) \\ Versión electrónica: rej.ujaen.es}


en el Pacto Internacional de Derechos Civiles y Políticos de 19 de diciembre de 1966, ratificado por España en Instrumento de 27 de abril de $1977 .{ }^{62}$

Como hemos adelantado, tampoco el derecho a la intimidad reconocido por el artículo 18.2 CE es absoluto y puede ser objeto de limitaciones, bien por resolución de la autoridad judicial, bien en situaciones de excepcionalidad constitucional, bien ante determinadas formas de delincuencia organizada.

Así, la propia CE prevé esta eventualidad en su artículo 55.1, en supuestos de anormalidad constitucional, cuando se acuerde el estado de excepción o de sitio, con arreglo a lo dispuesto en la Carta Magna y por supuesto ante un conflicto armado.

La intimidad, dice el TC es un derecho de personalidad que implica: " $L a$ existencia de un ámbito reservado frente a la acción y el conocimiento de los demás, ámbito que es necesario según las pautas de nuestra cultura, para mantener una calidad mínima de la vida humana", ${ }^{63}$ toda vez que lo que se protege mediante la intangibilidad del espacio físico es indirectamente aquella intimidad, que la persona ha decidido que se desarrolle dentro de dicho espacio limitado.

De ahí que la garantía que representa la no entrada en el domicilio sin la voluntad del morador, revista carácter instrumental en función de la mencionada finalidad a la que sirve de protección.

Exige el TEDH, que las posibles injerencias de los poderes públicos en éstos derechos, además de ser necesarias para conseguir una finalidad legal en una sociedad democrática, estén reguladas muy estrictamente por la ley, la cual debe fijar las modalidades y el alcance de las medidas, para que así las personas puedan protegerse contra la arbitrariedad.

Por su parte, los tribunales españoles Constitucional y Supremo extienden el concepto de domicilio, a estos efectos, a cualquier lugar donde efectivamente viva el interesado. ${ }^{64}$

Hemos de añadir, que de la importancia que se confiere a la protección de este derecho, da cuenta el sistema de garantías que tanto penales, como procesales se han establecido en evitación de arbitrariedades o ilegalidades, así, en los artículos 202 a 204 del Código Penal, ${ }^{65}$ se contempla entre los "Delitos contra la intimidad, el derecho a la propia imagen y la inviolabilidad del domicilio", el allanamiento de morada, domicilio de personas jurídicas y establecimientos abiertos al público, así como sus tipos agravados.

Este régimen de garantías penales se ha visto complementado por unas garantías de naturaleza procesal, tanto en el ámbito procesal penal, como en el procesal militar, estableciendo necesariamente que solo se podrá realizar la entrada en domicilio, respecto de los procesados y de los presuntos responsables de la comisión de un delito, cuando exista una autorización judicial, en la forma y con los requisitos que establecen nuestras normas procesales. ${ }^{66}$

\footnotetext{
${ }^{62}$ BOE núm. 103/1977, de 30 de abril. Art. 17: “Nadie será objeto de violaciones arbitrarias o ilegales en su vida privada, su familia, su domicilio o su correspondencia”.

${ }^{63}$ Vide. SSTC 231/1988, de 2 de diciembre; 197/1991, de 17 de octubre, 20 y 219/1992, de 14 de febrero; 142/1993, de 22 de abril; 117 y 143/1994, de 25 de abril; y 207/1996, de 16 de diciembre.

${ }^{64}$ Vide. STEDH de 27 de diciembre de 1983, caso Malone c. Reino Unido; STC 199/1987, de 16 de diciembre; STC 22/1984, de 17 de febrero; 50 y 133/1995, de 23 de febrero y 25 de septiembre; SSTS de 14 de enero, 10 de julio, 5 de octubre y 30 de diciembre de 1992, entre otras.

${ }^{65}$ Véase artículos 202 a 204 del Código Penal.

${ }^{66}$ En el artículo 546 de la LECrim se prescribe que: “El Juez o Tribunal que conociere de la causa podrá decretar la entrada y registro, de día o de noche, en todos los edificios y lugares públicos, sea cualquiera 
En igual sentido se pronuncia, para el ámbito de la jurisdicción militar, la Ley Orgánica 2/1989, de 13 de abril, Procesal Militar cuyo Capítulo VI, se dedica a regular la entrada y registro en lugar cerrado, prescribiendo en sus artículos 185 a 187, que le corresponde al Juez Togado Militar (Territorial o Central) autorizar por auto, previa audiencia del Fiscal Jurídico Militar y mediante el correspondiente mandamiento, estas intervenciones. ${ }^{67}$

La Ley Orgánica reguladora de los Derechos y Deberes de los miembros de las Fuerzas Armadas 9/2011, de 27 de julio, regula en su artículo 10.1 el derecho a la inviolabilidad del domicilio de los miembros de las FAS, al disponer “(...) También tiene derecho al secreto de las comunicaciones y a la inviolabilidad del domicilio, incluido el ubicado dentro de unidades, en los términos establecidos en la Constitución y en el resto del ordenamiento jurídico".

Debemos dejar patente que el derecho a la intimidad e inviolabilidad del domicilio que se contiene en el artículo $18 \mathrm{CE}$ resulta de aplicación a todos los ciudadanos, de los que los miembros de los Ejércitos no constituyen una excepción.

La Ley Orgánica 9/2011, de 27 de julio reguladora de los Derechos y Deberes de los miembros de las Fuerzas Armadas, en su artículo 3 dispone que:

"Los miembros de las Fuerzas Armadas son titulares de los derechos fundamentales y libertades públicas reconocidos en la Constitución, sin otros límites en su ejercicio que los establecidos en la propia Constitución, en las disposiciones que la desarrollan, en esta ley orgánica y en las leyes orgánicas penales y disciplinarias militares".

La libertad de residencia y circulación tiene límites lógicos para todos los funcionarios públicos, pero en el caso de los militares, el deber de presencia y disponibilidad es más exigente, tal y como demuestra su legislación disciplinaria y penal, lo que de alguna manera hace que en el ámbito propio de los Ejércitos, la libertad de residir se haya visto y se vea limitada.

Bien es cierto que el personal militar profesional, ya no está obligado a pernoctar, salvo que preste servicio de retén, en la unidad, centro, base o dependencia militar, sino que puede optar entre residir en las camaretas compartidas o "módulos de alojamiento" que se habilitan en su destino, en las residencia militares de tropa ubicadas en las unidades, o en el domicilio que fije en el exterior como cualquier ciudadano.

Pero como ya se advirtió, la especialidad de las misiones que constitucionalmente le han sido encomendadas a las Fuerzas Armadas y a sus miembros, así como la especialidad de los destinos del personal militar, con frecuentes cambios de localidad de manera forzosa, hacen que con asiduidad, se vean obligados a residir fuera de su domicilio familiar, y en un amplio abanico de habitáculos, lo cual genera problemas en torno a la determinación de cuáles de entre estos lugares pueden

el territorio en que radiquen, cuando hubiere indicios de encontrarse allí el procesado o efectos o instrumentos del delito, o libros, papeles u otros objetos que puedan servir para su descubrimiento y comprobación".

${ }^{67}$ Artículo 187 Ley Procesal Militar: "Podrá el Juez Togado acordar por medio de auto que será notificado al Fiscal Jurídico Militar, el registro de un domicilio o local, y la retención apertura y examen de la correspondencia privada, postal, telegráfica o grabada, relacionada con la investigación, que el procesado remitiere o recibiere, si hubiere posibilidad de obtener por estos medios el descubrimiento o la comprobación de algún hecho o circunstancia importante para la causa. También podrá ordenar que se traigan a los autos copia de los telegramas transmitidos o recibidos si concurren las mismas circunstancias". 
incluirse en el concepto de domicilio constitucionalmente merecedor de protección, especialmente a los efectos de la realización de entradas y registros y cuales no. ${ }^{68}$

Tal y como ya se ha indicado, el personal militar, tiene reconocido en el artículo 10 de la Ley Orgánica 9/2011, su derecho a la intimidad y dignidad personal, al secreto de las comunicaciones y a la inviolabilidad del domicilio y ese reconocimiento y por ende protección, abarca e incluye el ubicado dentro de unidades, en los términos establecidos en la Constitución, en el resto del ordenamiento jurídico y con las singularidades a las que nos vamos a referir a continuación.

Tampoco podemos pasar por alto las constantes revistas e inspecciones que habitualmente se desarrollan en las dependencias militares y que deben respetar en todo caso estos derechos, así como si el registro personal de los militares, de sus taquillas, efectos y pertenencias que estuvieren en la unidad y que tal y como dispone el artículo 10.2 del mismo texto legal:

“(...) Requiere del consentimiento del afectado o resolución judicial. No obstante, cuando existan indicios de la comisión de un hecho delictivo o por razones fundadas de salud pública o de seguridad, el jefe de la unidad podrá autorizar tales registros de forma proporcionada y expresamente motivada. Estos registros se realizarán con la asistencia del interesado y en presencia de al menos dos testigos o sólo de éstos, si el interesado debidamente notificado no asistiera". ${ }^{9}$

\section{Concepto de domicilio.}

Con carácter general podemos definir el domicilio, siguiendo al Tribunal Supremo, como: "El lugar cerrado, legítimamente ocupado, en el que transcurre la vida privada, individual o familiar, aunque la ocupación sea temporal o accidental". ${ }^{70}$

Llama la atención, tal y como apunta la profesora Navas Sánchez, que pese a su importancia, la CE no da una definición expresa de lo que debemos entender por domicilio a efectos constitucionales, por eso, y toda vez que la CE se limita a utilizar el término al afirmar que éste es inviolable, su concreción es obra no sólo del TS sino evidentemente, también de nuestro TC que ya, desde sus primeras resoluciones relativas a este derecho, dedica una atención preferente a construir un concepto constitucional del domicilio, claramente diferenciado de las nociones ya conocidas del mismo en otros sectores del ordenamiento jurídico como puede ser el civil o el penal. ${ }^{71}$

68 Vid. STC 189/2004, de 2 de noviembre.

69 La Sala Segunda del Tribunal Supremo ha tenido ocasión de manifestarse en relación al registro de taquillas, no dándoles a las mismas igual consideración que al domicilio a efectos de protección constitucional del derecho a la intimidad. En este sentido la sentencia de 9 de junio de 2000 hace referencia al argumento esgrimido por el recurrente de que: "La única prueba que cabe calificar como relevante en los hechos de los que dimana el presente recurso se ha obtenido ilícitamente mediante un procedimiento atentatorio contra el derecho constitucional a la intimidad del recurrente por cuanto no se trata tanto del hecho de que el registro se realice en el dormitorio común de un cuartel... que en cuanto dormitorio común carece de intimidad, como de que se practique respecto de las taquillas individuales que tienen asignadas cada soldado y que es el único espacio respecto del que cabe esperar que se respete su derecho a la intimidad". A ello argumenta la Sala, recordando otras sentencias (en concreto las de 26 de enero de 1995 y 8 de octubre de 1999) que este tipo de registros y en concreto las de revista de las taquillas existentes en los acuartelamientos, donde guardan sus enseres los soldados, no atenta a la intimidad personal: "Ya que ello viene reglamentariamente impuesto por las normas del buen gobierno y orden del estamento castrense, que vería resquebrajada en caso contrario la disciplina, e incluso la seguridad del propio acuartelamiento. Todo ello, claro está, siempre que al practicarse se respeten las garantías legalmente establecidas al respecto”.

${ }^{70}$ Vid. SSTS 11 de julio de 1996 y 6 de septiembre de 1999.

${ }^{71}$ Cfr.: Navas Sánchez, M.M.: ¿Inviolabilidad o intimidad domiciliaria?...op, cit, pp. 161.

Revista de Estudios Jurídicos nº 15/2015 (Segunda Época)

ISSN 1576-124X Universidad de Jaén (España)

Versión electrónica: rej.ujaen.es 
En base a una definición más técnica-jurídica, el domicilio es el ámbito territorial donde se ejercitan los derechos y se cumplen las obligaciones constituyendo la sede jurídica y legal de la persona. ${ }^{72}$

Para los profesores Queralt y Jiménez Quintana el domicilio es el espacio físico constante, separado por la voluntad de su morador del resto del espacio físico y en el que dicha persona vive sin estar sujeta necesariamente a los usos y convenciones sociales y en donde ejerce su libertad más íntima. ${ }^{73}$

La profesora Navas Sánchez entiende que el concepto de domicilio implica un lugar cerrado o al menos parcialmente cerrado que sirve a la finalidad constitucional de garantizar el libre desarrollo del individuo y de su personalidad. ${ }^{74}$

Siguiendo a Alonso de Antonio, podemos decir que no se debe entender el domicilio por lo que es, sino por lo que representa, es decir, hablando en términos generales, no importa tanto o solamente el elemento material que conocemos como domicilio, sino que lo que importa es realmente el desarrollo integral del ser humano a todos los niveles que puede amparar el dato físico "domicilio.",75

En este sentido, el contenido jurídico de domicilio va más allá de la acepción vulgar del término "lugar donde uno vive", siendo necesaria su delimitación para el ámbito del derecho.

Algunos autores han defendido la existencia de un concepto constitucional de domicilio, ${ }^{76}$ otorgando una significación propia a tal término, distinta a la establecida en el derecho privado-civil.

Para Alonso de Antonio, por el contrario, no existe un concepto constitucional de domicilio, pues no se puede extraer como tal de la redacción del texto constitucional. $^{77}$

Será necesario acudir a la jurisprudencia y a la doctrina para suplir esta falta de definición de los textos legales.

A la hora de definir el concepto de domicilio se impone buscar un concepto global, pero a la vez estricto. Es decir, una definición más allá del contenido privativo o de otras parcelas del ordenamiento jurídico ${ }^{78}$ civil, administrativo o penal y, estricto porque supone delimitar una serie de parámetros que nos ayudarán a distinguir qué es domicilio de lo que no lo es. $^{79}$

Para el TC el domicilio es: "Un espacio en el cual el individuo vive sin estar sujeto necesariamente a los usos y convenciones sociales y ejerce su libertad más intima". Mientras que el derecho a la inviolabilidad del domicilio lo define como un auténtico derecho fundamental de la persona, establecido para garantizar el ámbito de privacidad de ésta dentro del espacio que la propia persona elige y que tiene que

\footnotetext{
${ }^{72}$ Cfr.: Diccionario Básico Jurídico. Editorial Comares, 4a edición. Granada. 1994, pp. 172 y 173.

${ }^{73}$ Cfr.: Queralt, J.J.; y Jiménez Quintana, E.: Manual de Policía Judicial. Ministerio de Justicia. Madrid. 1987, pp. 84-85.

${ }^{74}$ Cfr.: Navas Sánchez, M.M.: ¿Inviolabilidad o intimidad domiciliaria?...op, cit, pp. 188.

${ }^{75}$ Cfr.: Alonso de Antonio, A.L.: El derecho a la inviolabilidad domiciliaria en la Constitución Española...op, cit, pp. 63.

${ }^{76}$ Cfr.: González- Trevijano, P.J.: La inviolabilidad del domicilio...op, cit, pp. 145.

${ }^{77}$ Cfr.: Alonso de Antonio, A.L.: El derecho a la inviolabilidad domiciliaria...op, cit, pp. 84.

${ }^{78}$ Cfr.: González- Trevijano, P.J.: La inviolabilidad del domicilio...op, cit, pp. 132 y ss.

${ }^{79}$ Cfr.: Alonso de Antonio, A.L.: El derecho a la inviolabilidad domiciliaria en la Constitución Española...op, cit, pp. 85 y ss.
}

$$
\begin{gathered}
\text { Revista de Estudios Jurídicos no 15/2015 (Segunda Época) } \\
\text { ISSN 1576-124X Universidad de Jaén (España) } \\
\text { Versión electrónica: rej.ujaen.es } \\
\text { - } 16 \text { - }
\end{gathered}
$$


caracterizarse precisamente por quedar exento o inmune a las invasiones o agresiones exteriores, de otras personas o de la autoridad pública.

Por ello, a través de este derecho no solo es objeto de protección el espacio físico en sí mismo considerado, sino lo que en él hay de emanación de la persona y de esfera privada de ella. ${ }^{80}$

Por consiguiente, es claro que, por ejemplo, un local no puede considerarse domicilio, ni tampoco ninguna dependencia no destinada a vivienda o vinculada directamente con el ejercicio de los actos de la libertad más íntima que se ejecutan de forma asidua en los domicilios o viviendas.

Así, la jurisprudencia de la Sala $2^{\mathrm{a}}$ del Tribunal Supremo ${ }^{81}$ considera que una oficina o local comercial carecen de la protección que otorgan los apartados 1 y 2 del artículo $18 \mathrm{CE}$, al no constituir un espacio de privacidad necesario para el libre desarrollo de la personalidad. Por eso no pueden considerárseles incluidos dentro del ámbito de protección de la inviolabilidad del domicilio. ${ }^{82}$

“(...) Ni toda entrada y registro en un lugar cerrado exige la autorización judicial, ni los locales comerciales o almacenes que no constituyen morada de una persona gozan de la tutela constitucional del art. $18.2 \mathrm{CE}$, sin que requieran, en consecuencia, para la entrada y registro en ellas de las mismas formalidades procesales que se imponen a los registros domiciliarios". 83

En la STS Sala $2^{a}$ de 6 de marzo de 2013, el TS se pronuncia sobre el concepto de domicilio, al delimitar la consideración de tal, respecto de un local dedicado a trastero, llegando a la conclusión, de que según tiene afirmado esta Sala, un trastero o almacén destinado a guardar objetos, sin comunicación directa con la vivienda, no puede considerarse domicilio al no tener relación con el ámbito de privacidad constitucionalmente protegido no siéndole, por lo tanto, aplicables a la entrada y registro en el mismo las reglas derivadas de la protección constitucional del derecho a la inviolabilidad del domicilio. ${ }^{84}$

Por ello a través de este derecho fundamental no solo se protege el espacio físico en sí mismo considerado, sino lo que en él hay de emanación de la persona y de su esfera privada, con lo que también se comprenden los espacios cerrados en donde se realiza privadamente una actividad laboral (por ejemplo, despachos profesionales, oficinas, almacenes, etc., siempre que los titulares tengan la facultad de excluir a terceros). ${ }^{85}$

Ahora bien, el concepto de domicilio no puede ceñirse estrictamente al del lugar que sirve de morada habitual del individuo. ${ }^{86}$ El concepto subyacente en el artículo 18.2 de la Constitución, ha de entenderse de modo flexible y amplio, ya que trata de defender los ámbitos en que se desarrolla la vida privada de las personas, debiendo interpretarse a la luz de los principios que tienden a extender al máximo la protección a la dignidad y a

\footnotetext{
${ }^{80}$ Cfr.: Navas Sánchez, M.M.: ¿Inviolabilidad o intimidad domiciliaria?...op, cit, pp. 161;Véase también STC 137/1985, 69/1999, 94/1999 y 119/2001.

${ }^{81}$ Vide. STS de 17 de octubre de 2005 y STS de 18 de febrero de 2005.

${ }^{82}$ Vide. SSTS de 27 de julio de 2002; 3 de octubre de 1995 y 27 de octubre de 1993.

${ }^{83}$ Vid. STS 8 de julio de 1994.

${ }^{84}$ Vide. SSTS 282/2004, de 1 de marzo; 616/2005 de 12 de mayo; 929/2009 de 7 de octubre y 143/2013, de 28 de febrero.

${ }^{85}$ Vide. STC 22/ 1984, de 17 de febrero.

${ }^{86}$ Vide. STS 1803/2002, de 4 de noviembre.
}

Revista de Estudios Jurídicos nº 15/2015 (Segunda Época)

ISSN 1576-124X Universidad de Jaén (España) Versión electrónica: rej.ujaen.es 
la intimidad de la persona, al desarrollo de su privacidad, a través de la cual proyecta su yo anímico en múltiples direcciones. ${ }^{87}$

Por tanto, entendemos que el rasgo esencial del concepto de domicilio como objeto de protección constitucional en el art. 18.2 CE es el de "constituir un ámbito espacial apto para un destino específico; el desarrollo de la vida privada" ${ }^{88}$ de modo que se identifica con la morada de las personas físicas y con la idea de reducto último de su intimidad personal y familiar. ${ }^{89}$

Como señala Luzón Cuesta, ${ }^{90}$ no debemos olvidar que el concepto "domicilio" en su acepción etimológica, deriva de "domus" y de "colere”, términos latinos que equivalen a habitar una casa, significando el término “domicilium”, casa, habitación, estancia o morada; y según el Diccionario de la Real Academia de la Lengua Española, tiene los siguientes significados: "morada fija o permanente", "casa que uno habita o se hospeda" y "lugar en que legalmente se considera establecida una persona para el cumplimiento de sus obligaciones y ejercicio de sus derechos”, este es el concepto habitual de domicilio.

A los efectos de delimitación de la protección constitucional del artículo 18 CE, acudiremos a las definiciones que se dan en el ámbito civil y penal.

En los artículos 40 y 41 del Código Civil, se señala el domicilio de las personas naturales y el de las personas jurídicas, estableciendo que el de las primeras lo será: “El lugar de la residencia habitual y en su caso el que determina la Ley de Enjuiciamiento Civil", para ejercitar sus derechos y cumplir con sus obligaciones civiles; y respecto de las personas jurídicas, lo será el del lugar donde tengan establecida: "Su representación legal o donde se ejerzan las principales funciones".

Por otro lado, en el ámbito penal, el artículo 202.1 del Código Penal de 1995, prescribe que comete el delito de allanamiento de morada: "El particular que, sin habitar en ella, entre en morada ajena o se mantuviere en la misma contra la voluntad de su morador". Precepto que queda complementado por el artículo 554.2 de la Ley de Enjuiciamiento Criminal que da un concepto legal de domicilio considerando como tal: "El edificio o lugar cerrado, o la parte de él destinada principalmente a la habitación de cualquier español o extranjero residente en España y de su familia”.

Mayor amplitud da el artículo 91.2 de la Ley Orgánica del Poder Judicial, señalando que no sólo constituye domicilio, en el ámbito de protección de la intimidad, la "habitación” o "morada”, añadiendo también otros "edificios de acceso dependiente del consentimiento del titular", que no constituyen morada "stricto sensu".

Como ya adelantamos en renglones anteriores, será en la STC 22/1984, en su FJ 5 en la que el propio TC nos de un concepto constitucional de domicilio al señalar que: "El domicilio inviolable es un espacio en el cual el individuo vive sin estar sujeto necesariamente a los usos y convenciones sociales y ejerce su libertad más íntima”. ${ }^{1}$

\footnotetext{
${ }^{87}$ Vid. STS de 19 de enero; STS de 4 de abril de 1995; y STS de 30 de abril de 1996.

${ }^{88}$ Vide. SSTC 10/2002, de 17 de enero y 209/2007, de 24 de septiembre.

${ }^{89}$ Vid. STC 283/2000, de 27 de noviembre.

${ }^{90}$ Cfr.: Luzón Cuesta, J.M.: La prueba en el proceso penal derivada de la entrada y registro en domicilio. Biblioteca Jurídica de bolsillo, nº 43. Editorial Colex. Madrid, pp. 15 y ss.

${ }^{91}$ En el mismo sentido, la STS de19 de enero de 1995 (Ponente Bacigalupo Zapater), recoge el concepto de domicilio, manifestando en su FJ 3 que: “(...) La protección del domicilio no es sino un aspecto de la protección de la intimidad que sirve al libre desarrollo de la personalidad. De ello se deduce que el domicilio, en el sentido de la Constitución, no sólo es el lugar donde se pernocta habitualmente o donde se realizan otras actividades cotidianas habituales, sino también el ámbito cerrado erigido por una
} 
Al amparo del artículo 8 del CEDH, también se ha pronunciado el TEDH sobre los espacios susceptibles de ser considerados y por ende protegidos, como domicilio, ${ }^{92}$ así:

1. Se considera domicilio la vivienda de una persona que la mantuvo desalojada durante un tiempo por haber fijado su residencia en el extranjero. ${ }^{93}$

2. Se incluyen los locales anejos a la vivienda en la que se desarrolla la actividad comercial del morador. ${ }^{94}$

3. Engloba los despachos profesionales de quiénes ejercen una profesión liberal. $^{95}$

4. No cabe la violación del domicilio y su registro en una investigación policial sin mandamiento judicial. ${ }^{96}$

Y resultan de especial interés, los pronunciamientos del TEDH en el caso Isildak contra Turquía en su STEDH de 30 de septiembre de 2008 en la que interpreta que existe injerencia en el derecho al respeto del domicilio. ${ }^{97}$

El TEDH parte de una noción amplia de domicilio, al recordar que el concepto de "domicilio" que figura en el artículo 8 del CEDH , es un concepto autónomo, que no depende de una calificación en derecho interno.

Es decir, la cuestión de si una vivienda particular constituye un “domicilio” amparado por la protección del citado artículo 8 CEDH dependerá de las circunstancias factuales, principalmente la existencia de vínculos suficientes y continuos con un lugar determinado.

El término “domicilio" tiene por tanto una connotación más amplia que la palabra "home" que figura en la versión inglesa del artículo 8 CEDH. Puede englobar, por ejemplo, la oficina o el despacho de un miembro de una profesión liberal. ${ }^{98}$

persona con objeto de desarrollar en él alguna actividad. (...). La legislación ordinaria no ha concretado de una manera expresa el concepto constitucional de domicilio, como ámbito de intimidad protegible. Sin embargo, el art. 87.2 LOPJ demuestra que el ámbito de intimidad que corresponde al derecho fundamental es más amplio que el de habitación o morada. Esa disposición reconoce la existencia de «domicilios» y de otros «edificios o lugares de acceso dependiente del consentimiento del titular», es decir que no constituyen morada en sentido estricto. Es claro, por tanto, que el establecimiento de un ámbito de intimidad constitucionalmente protegible no está vinculado a la habitación en sí misma, sino al libre desarrollo de la personalidad y, consecuentemente, no necesita estar físicamente vinculado al ámbito espacial en el que el ciudadano habita con cierta permanencia”. Véase también STS de 19 de marzo de 2001 y SSTS de 19 de enero, 4 de abril de 1994 y de 30 de abril de 1996.

92 Sobre ésta materia, véase Morenilla Rodríguez, J.M.: «El derecho al respeto de la vida privada en la jurisprudencia del TEDH». En la Jurisprudencia del TEDH. CGPJ. Madrid. 1993, pp. 317 y ss.

${ }^{93}$ Vid. STEDH de 24 de noviembre de 1984, caso Gillow c. Reino Unido.

${ }^{94}$ Vid. STEDH de 20 de marzo de 1989, caso Chapell c. Reino Unido.

${ }^{95}$ Vid. STEDH de 16 de diciembre de 1992, caso Nimietz c. Alemania.

${ }^{96}$ Vid. STEDH de 25 de febrero de 1993, caso Funke, Cremieux y Miailhe c. Francia o STEDH de 9 de diciembre de 1994, caso López Ostra, c. España.

$97 \mathrm{El}$ fondo del asunto, versa sobre un ciudadano turco, el señor Sadi Isildak, nacido en 1966 y residente en Estambul, que era arrendatario de un taller dedicado a ferrería, con uso igualmente de vivienda, situado en el número 39 de la calle Bostan Haman. El 8 de noviembre de 2000, el demandante Sr. Isildak presentó una denuncia ante la fiscalía de Fatih y la prefectura de Estambul, en la que explicaba que la víspera, entre las 19 y 21 horas, dos policías habían realizado una visita a su taller y que uno de ellos, llamado Yusuf, entró por la puerta del taller sin su autorización y posteriormente entró hasta la habitación. El policía en cuestión declaró que se decían “cosas malas” sobre él y le acusó de consumir cannabis.

${ }^{98}$ Vide. STEDH de 16 de diciembre de 1992 caso Niemietz contra Alemania.

Revista de Estudios Jurídicos nº 15/2015 (Segunda Época)

ISSN 1576-124X Universidad de Jaén (España)

Versión electrónica: rej.ujaen.es 
En el caso Isildak, el TEDH se pregunta si la injerencia en el domicilio estaba justificada de acuerdo con el párrafo 2 del artículo 8 del Convenio, es decir, si estaba prevista por la ley, perseguía una o varias finalidades legítimas y era necesaria en una sociedad democrática para alcanzarlas.

La respuesta que da el propio TEDH es negativa, al señalar que no ocurrió así en el referido caso. En la época en que se produjeron los hechos -argumenta la sentenciala policía turca podía proceder a un registro sin autorización previa. Tenía competencia para apreciar sólo la oportunidad de un registro y el alcance de éste.

En vista de lo que antecede, el Tribunal considera que las disposiciones legales en vigor en la época de los hechos no preveían de manera suficiente las garantías para evitar que las autoridades no pudieran adoptar medidas arbitrarias vulnerando el derecho del demandante al respeto de su domicilio. Hubo, por tanto, violación del artículo 8 del Convenio.

Sobre la base de la inexistencia de garantías para proteger la inviolabilidad de domicilio, el TEDH defiende un concepto amplio de domicilio, capaz de proteger su titularidad, sea de personas físicas o jurídicas.

El contraste, por tanto, entre la noción de domicilio que maneja esta STEDH de 30 de septiembre de 2008 (caso Isildak), sobre la base de la jurisprudencia anterior, permite señalar algunas convergencias o alineamientos paralelos, más allá de la diversa dicción legal del artículo 18.3 CE y artículo 8 del Convenio.

En primer lugar, puede señalarse que las similitudes parten del manejo de un concepto amplio de domicilio en la línea que sostuvo la STC de 17 de febrero de 1984 al defender y concretar una dimensión del concepto constitucional de domicilio, más amplia del que se utiliza en derecho privado.

Dice así la precitada sentencia: ${ }^{99}$

"La protección constitucional del domicilio es una protección de carácter instrumental, que defiende los ámbitos en que se desarrolla la vida privada de la persona. Por ello existe un nexo de unión indisoluble entre la norma que prohíbe la entrada y el registro en un domicilio (art. 18.2 de la Constitución) y la que impone la defensa y garantía del ámbito de privacidad (art. 18.1 de la Constitución)...”

El artículo 18, apartado 2, de la Constitución contiene dos reglas distintas; una tiene carácter genérico o principal, mientras la otra supone una aplicación concreta de la primera y su contenido es por ello más reducido.

La regla primera define la inviolabilidad del domicilio, que constituye un auténtico derecho fundamental de la persona establecido, para garantizar el ámbito de privacidad de ésta dentro del espacio limitado que la propia persona elige y que tiene que caracterizarse precisamente por quedar exento o inmune a las invasiones o agresiones exteriores de otras personas o de la autoridad pública.

El domicilio inviolable es un espacio en el cual el individuo vive sin estar sujeto necesariamente a los usos y convenciones sociales y ejerce su libertad más íntima.

Por ello a través de este derecho, no sólo es objeto de protección el espacio físico en sí mismo considerado, sino lo que en él hay de emanación de la persona y de esfera privada de ella. Interpretada en este sentido, la regla de la inviolabilidad del domicilio es de contenido amplio, e impone una extensa serie de garantías y de facultades, en las que se comprenden las de vedar toda clase de invasiones, incluidas las

\footnotetext{
${ }^{99}$ Vid. STC de 17 de febrero de 1984, Fundamento Jurídico 2 y 5.

Revista de Estudios Jurídicos nº 15/2015 (Segunda Época)

ISSN 1576-124X Universidad de Jaén (España)

Versión electrónica: rej.ujaen.es
} 
que puedan realizarse sin penetración directa por medio de aparatos mecánicos, electrónicos u otros análogos.

En segundo lugar, la jurisprudencia de ambos tribunales coincide en la defensa de una intimidad domiciliaria libre de injerencias o intromisiones no permitidas por la ley o por la Constitución en nuestro caso.

Para finalizar con el concepto de domicilio, añadiremos, que el mismo, desde el punto de vista constitucional, tiene unas notas propias o específicas, imprecisas a veces, que lo distinguen de las nociones propias del derecho civil o penal, cuyos rasgos esenciales de delimitación consisten en:

a) Que su uso o destino sea el ejercicio de aquella privacidad esencial e íntima (elemento objetivo);

b) Que el interés del titular del derecho debe consistir en establecer en dicho espacio su ámbito privado, conforme a su libre elección derivada del derecho al libre desarrollo de la personalidad (art. 10.1 CE);

c) Que la determinación de la ubicación confiera al titular del derecho capacidad de exclusión de terceros, comprendido el Estado; y

d) Que los potenciales titulares son tanto las personas físicas como las jurídicas.

\section{Residencias militares.}

Comenzamos el estudio de las residencias militares a efectos domiciliarios, con la convicción de que son susceptibles de ser consideradas como tal. ${ }^{100}$

No cabe duda alguna de que las habitaciones de las residencias de los militares en la medida en que sean lugares idóneos, por sus propias características, para que en las mismas se desarrolle la vida privada y efectivamente estén destinadas a tal desarrollo, aunque sea eventual, constituyen el domicilio de quienes las tienen asignadas a los efectos de la protección que les dispensa el art. 18.2 CE, por lo que la entrada en

${ }^{100}$ Vide. STC 189/2004, de 2 de noviembre, FJ 2 y FJ 4. En la STC núm. 189/2004, de 2 de diciembre, el Alto Tribunal otorgó el amparo solicitado a un suboficial del Ejército de Tierra que había sido desalojado, en su ausencia, de la habitación que ocupaba en una residencia militar. Al citado suboficial se le ordenó el desalojo de la habitación por el impago de las mensualidades, acordado por el coronel director de la residencia en aplicación de lo establecido por las normas de régimen interior del centro; tras reiterados apercibimientos para que abandonara la habitación, acordó el director la entrada en el alojamiento a fin de, tras extraer todos sus enseres personales, alojar a otro residente. Para ello el coronel director designó a dos oficiales de mayor empelo militar que el suboficial para que comparecieran en calidad de testigos a presenciar la entrada y retirada de efectos de la habitación, procediendo a la realización de un inventario de los mismos, a su inmediato embalaje, cierre y precintado, caso de que el desalojo no se produjera voluntariamente, notificando dicha circunstancia al afectado. Al no abandonar su residencia, se procedió a cumplimentar la orden del director. Para ello, se personaron en la habitación la gobernanta de la residencia, asistida de un oficial, un suboficial y de dos miembros de la policía militar, accediendo a la habitación del residente y desalojando sus efectos personales en las condiciones señaladas.

Esta actuación fue objeto de la correspondiente denuncia ante el Juzgado Togado Militar Central, quién acordó el archivo de las actuaciones reputando legítima la entrada, fundamentando la resolución en que el demandante había perdido la condición de usuario de la residencia y así se le había notificado, por lo que: “La ocupación legítima del alojamiento había finalizado, siendo necesario dejar libre la habitación para su uso de posibles nuevos residentes, operaciones de limpieza y vaciado de armarios... sin que conste que el denunciante hubiera interpuesto recurso contencioso- administrativo contra la resolución administrativa, no considerando se hubiera cometido delito alguno, abuso de autoridad, allanamiento de morada, ni violación de domicilio". Resolución que fue confirmada por el Tribunal Militar Central en auto de fecha 24 de enero de 2002, ratificando los razonamiento del Juzgado Togado. Planteado el amparo ante el Tribunal Constitucional, fue otorgado. 
las mismas sólo podrá realizarse si media consentimiento o en su defecto autorización judicial. ${ }^{101}$

Las residencias militares con las que cuentan los tres Ejércitos, son gestionadas por el Ministerio de Defensa y están ubicadas tanto dentro como fuera de acuartelamientos y bases militares. Su régimen de vida y gobierno es distinto del establecido para los "módulos de alojamiento de tropa", pues son dirigidas por directores militares, en régimen de alojamiento en habitaciones individuales, donde se desarrolla la vida privada de los militares que son admitidos a residir, con sometimiento a unas normas de régimen interior, que tan solo marcan pautas para la mejor convivencia de quiénes residen en ellas, o las preferencias en el derecho a la asignación de las mismas o a su desalojo por pérdida del derecho a su uso y en las que se puede desarrollar un ámbito de vida familiar al admitirse la convivencia con la pareja. Se trata de residencias en las que con frecuencia se permite el alojamiento, por breves períodos de tiempo, de familiares de los militares o de funcionarios dependientes del Ministerio de Defensa.

La finalidad primordial de estas residencias es facilitar alojamiento a los militares cuando llegan a la plaza donde radica su destino, dada la gran movilidad que conlleva su profesión y de ahí que sus precios sean considerablemente más bajos que en otros establecimientos de hospedaje, al tratarse de “dependencias militares”.

Su régimen interior se regula por la autoridad o mando militar que puede utilizar el "ius variandi" cuando las necesidades lo requieran, permitiendo incluso el alojamiento de familias enteras, siendo libre el militar también en este supuesto, de aceptar la normativa que rige el establecimiento o residir en cualquier otro lugar. ${ }^{102}$

Para nuestro TC la habitación asignada en una residencia militar a una persona constituye domicilio y, por tanto, goza de la protección que le dispensa el artículo 18.2 CE.

Parte el TC de la doctrina de ese órgano en las SSTC núm. 10/2002, de 17 de enero (FFJJ 5 y 6) y 22/2003, de 10 de febrero, en las que se proclama la inviolabilidad del domicilio y la interdicción de la entrada y registro domiciliarios, de modo que el derecho proclamado en el artículo 18 de la CE tiene por objeto: "La protección de un ámbito reservado de la vida de las personas excluido del conocimiento de terceros, sean éstos poderes públicos o particulares, en contra de su voluntad, el derecho a la inviolabilidad del domicilio protege «un ámbito espacial determinado» dado que en él ejercen las personas su libertad más íntima, libres de toda sujeción a los usos y

\footnotetext{
${ }^{101}$ Vide. STC 22/1984 FJ 4. Véase también la sentencia de 2 de noviembre de 2003 del Tribunal Constitucional en la que igualmente el máximo intérprete constitucional considera domicilio la habitación de una residencia militar ocupada como residente por un brigada del Ejército de Tierra.

${ }^{102}$ La Orden Ministerial 346/98, de 23 de diciembre, regulaba y definía las residencias militares, considerando a éstas como establecimientos de apoyo al personal que facilitan el alojamiento y otros servicios complementarios a los militares profesionales de carrera destinados en las unidades ubicadas en la propia base o acuartelamiento y en aquellas otras bases o acuartelamientos que se determinen por el órgano gestor. Esta Orden Ministerial, ha sido sustituida por la Orden Ministerial 13/2009 a fin de adaptar la normativa existente a las previsiones de la Ley 39/2007 de la Carrera Militar y con el objeto a su vez de adecuar el conjunto de residencias militares a las necesidades del personal militar, adaptando especialmente los usos posibles de estas residencias y usuarios, incluidas las correspondientes revisiones de precios. Esta Orden Ministerial 13/2009 define las residencias militares como: “Los establecimientos para apoyo y asistencia al personal militar que proporcionan alojamiento $y$ otros servicios complementarios a los miembros de las FAS, así como, en su caso y con los criterios que se determinen, a sus familiares".
}

\section{Revista de Estudios Jurídicos nº 15/2015 (Segunda Época) \\ ISSN 1576-124X Universidad de Jaén (España) \\ Versión electrónica: rej.ujaen.es}


convenciones sociales, siendo objeto de protección de este derecho tanto el espacio físico en sí mismo considerado, como lo que en él hay de emanación de la persona y de su esfera privada”.

El propio carácter instrumental de la protección constitucional del domicilio respecto de la protección de la intimidad personal y familiar exige que, con independencia de la configuración física del espacio, sus signos externos revelen la clara voluntad de su titular de excluir dicho espacio y actividad desarrollada del conocimiento de intromisiones de terceros, de lo que se extrajo como lógica consecuencia que:

"Las habitaciones de los hoteles pueden constituir domicilio de sus huéspedes, ya que, en principio, son lugares idóneos, por sus propias características, para que en las mismas se desarrolle la vida privada de aquellos, habida cuenta de que el destino usual de la habitación de los hoteles es realizar actividades enmarcables genéricamente en la vida privada". ${ }^{103}$

El Alto Tribunal en su sentencia de 24 de septiembre de 2007, aplica su doctrina a las habitaciones de las residencias militares ${ }^{104}$ considerándolas con mayor razón aún domicilio, ya que sus habitaciones son ocupadas por quienes son definidos en las normas de régimen interior de la residencia militar como usuarios permanentes y la función principal de estos alojamientos es facilitar aposentamiento a los militares destinados en una determinada plaza, como expresamente preveía la Orden Ministerial 346/1996 que regulaba su uso y la actual Orden Ministerial 13/2009 que la sustituye.

Por tanto, la residencia militar, se encuentra en la definición de domicilio inviolable en el sentido del art. 18.2 CE ya que al fin y al cabo, se trata de un espacio en el cual el militar vive sin estar sujeto necesariamente a los usos y convenciones sociales y ejerce su libertad más íntima. ${ }^{105}$

Existe así un "nexo indisoluble" entre la sacralidad de la sede existencial de la persona, que veda toda intromisión y, en concreto, la entrada y el registro en ella y de ella, con el derecho a la intimidad, por lo demás contenido en el mismo precepto. ${ }^{106}$

Ello significa en primer término, que su destino o uso constituye el elemento esencial para la delimitación de los espacios constitucionalmente protegidos, de modo que, en principio, son irrelevantes su ubicación, su configuración física, su carácter mueble o inmueble, la existencia o tipo de título jurídico que habilite su uso, o, finalmente, la intensidad y periodicidad con la que se desarrolle la vida privada en el mismo.

En segundo lugar, si bien el efectivo desarrollo de vida privada es el factor determinante de la aptitud concreta para que el espacio en el que se desarrolla se considere domicilio, de aquí no se deriva necesariamente que dicha aptitud no pueda inferirse de algunas de estas notas, o de otras, en la medida en que representen características objetivas conforme a las cuales sea posible delimitar los espacios que, en general, pueden y suelen ser utilizados para desarrollar vida privada. ${ }^{107}$

Toda vez que nuestro TC equipara las habitaciones del hotel, con las habitaciones de la residencia militar a los efectos de considerar ambas como

\footnotetext{
${ }^{103}$ Vid. SSTC 94/1999, de 31 de mayo, FJ 5 y 10/2002, FJ 6 in fine.

${ }^{104}$ Vid. STC 22/1984, de 17 de febrero FJ 2.

${ }^{105}$ Vide. STC 22/1984, de 17 de febrero FJ. 5; también, entre otras, SSTC 50/1995, de 23 de febrero FJ5; 133/1995, de 25 de septiembre, FJ4; 10/2002, de 17 de enero, FJ5 y 189/2004, de 2 de noviembre, FJ 2.

${ }^{106}$ Vide. STC 50/1995, de 23 de febrero, FJ5.

${ }^{107}$ Vid. SSTC 10/2002, de 17 de enero FJ7; 189/2004, FJ2.
}

Revista de Estudios Jurídicos nº 15/2015 (Segunda Época)

ISSN 1576-124X Universidad de Jaén (España)

Versión electrónica: rej.ujaen.es 
"domicilio", resulta interesante traer a colación que para el máximo intérprete constitucional: "Ni la accidentalidad, temporalidad, o ausencia de habitualidad del uso de la habitación del hotel, ni las limitaciones al disfrute de las mismas que derivan del contrato de hospedaje, pueden constituir obstáculos a su consideración como domicilio de los clientes del hotel mientras han contratado con éste su alojamiento en ellas, pues son espacios aptos para el desarrollo o desenvolvimiento de la vida privada, siempre que en ellos se desarrolle". ${ }^{108}$

Siendo las habitaciones de los hoteles y por analogía las habitaciones de una residencia militar espacios aptos para el desarrollo o desenvolvimiento de la vida privada, siempre que en ellos se desarrolle, constituyen ámbitos sobre los que se proyecta la tutela que la Constitución garantiza en su art. 18.2, su inviolabilidad y la interdicción de las entradas o registros sin autorización judicial o consentimiento de su titular, fuera de los casos de flagrante delito.

En la STC de 2 de noviembre de $2004,{ }^{109}$ el TC conoció de una actuación de desalojo del demandante de la habitación que ocupaba en una residencia militar y que se llevó a cabo en cumplimiento de lo prevenido en las normas de régimen interior de la misma.

Estas normas disponen, que una vez se pierde la condición de usuario del establecimiento, dicha novedad será comunicada al interesado por el coronel director, al tiempo que le señalará la obligación de dejar la habitación que ocupa.

En el supuesto de la sentencia que citamos, en ningún momento hubo resolución judicial concerniente al desalojo del recurrente, que efectuara una ponderación de sus intereses y derechos, incluidos, desde luego, los referentes al domicilio.

Se trató por tanto, de una actividad de la Administración de ejecución forzosa de sus propios actos amparada en el privilegio de la denominada autotutela administrativa, que no es contrario a la Constitución, sino que engarza con el principio de eficacia enunciado en el art. 103 CE. ${ }^{110}$

Ahora bien, dice el TC que esta prerrogativa, sin embargo, no puede primar sobre el contenido de los derechos y libertades de los ciudadanos ${ }^{111}$ por lo que en los actos de ejecución, la Administración tiene que respetar los derechos fundamentales de los sujetos pasivos de ella, de suerte que cuando resultan necesarios la entrada o el registro en el domicilio de una persona para llevarlos a cabo, será preciso dar cumplimiento a los requisitos del artículo $18 \mathrm{CE}$.

De este modo, dado que constitucionalmente la Administración se encuentra inhabilitada por el art. 18.2 CE para autorizar la entrada en domicilio, el acto administrativo que precisa una ejecución que sólo puede llevarse a cabo ingresando en un domicilio privado, no conlleva por sí solo el mandato y la autorización del ingreso, lo que implica que cuando éste es negado por el titular debe obtenerse una resolución judicial que autorice la entrada y las actividades que una vez dentro del domicilio pueden ser realizadas. ${ }^{112}$

\footnotetext{
${ }^{108}$ Vide. STC 10/2002 de 17 de enero FJ 8.

${ }^{109}$ Véase el fondo del asunto referido en la nota al pie $n^{\circ} 97$.

${ }^{110}$ Vide. SSTC 22/1984, de 17 de febrero; 238/1992, de 17 de diciembre, 148/1993, de 29 de abril; 78/1996, de 20 de mayo y 199/1998, de 13 de octubre.

${ }^{111}$ Vide. SSTC 22/1984, de 17 de febrero; 171/1997, de 14 de febrero y 199/1998, de 13 de octubre.

${ }^{112}$ Vide. SSTC 22/1984, de 17 de febrero; 211/1992, de 30 de noviembre; SSTC 76/1992 de 14 de mayo y 199/1998 de 13 de octubre.
}
Revista de Estudios Jurídicos nº 15/2015 (Segunda Época)
ISSN 1576-124X Universidad de Jaén (España)
Versión electrónica: rej.ujaen.es


En estos casos, el control que corresponde hacer al juez es el de garante del derecho fundamental a la inviolabilidad del domicilio, lo cual significa que no es el juez de la legalidad y de la ejecutividad del acto de la Administración, sino el juez de la legalidad de la entrada en domicilio. ${ }^{113}$

Sin este control, el acto es ilícito y constituye violación del derecho, salvo el caso de flagrante delito y salvo naturalmente hipótesis excepcionales, como puede ocurrir con el estado de necesidad.

Por lo tanto, conforme a la propia doctrina del Alto Tribunal, en el caso que se examina debió recabarse una resolución judicial previa para la penetración en el ámbito protegido por el derecho fundamental a la inviolabilidad domiciliaria.

Y ello sin entrar a considerar la legalidad y los efectos de la resolución dictada por el sr. coronel director de la residencia militar apercibiendo al demandante para que desalojara la habitación que le había sido asignada, ni las consecuencias de la decisión relativa al desalojo, ni las posibles resoluciones adoptadas o por adoptar por el orden jurisdiccional contencioso-administrativo al que acudió en su momento el recurrente para impugnar las normas de régimen interior.

La habitación asignada a una persona en un establecimiento de estas características tiene indudablemente la consideración de domicilio. Por tanto, la decisión de ejecutar un acto administrativo y entrar en una de estas habitaciones sin autorización judicial, contra o cuando menos sin la voluntad de su ocupante y de extraer de la misma sus pertenencias, enseres y efectos personales, integra una lesión del derecho fundamental a la inviolabilidad domiciliaria, así como el incumplimiento de lo preceptuado en el art. 8.5 de la Ley de la Jurisdicción Contencioso-Administrativa. ${ }^{114}$

\section{Viviendas Militares.}

La movilidad a lo largo de la trayectoria profesional del militar es una característica o exigencia relevante que contribuye eficazmente a su capacitación y a la operatividad de los Ejércitos.

Por ello, se han ido aplicando a lo largo del tiempo diversas políticas de vivienda militar, orientadas a facilitar la citada movilidad con objeto de asegurar que las unidades militares puedan disponer en todo tiempo de los profesionales adecuados y que estos puedan desarrollar trayectorias enriquecedoras del propio perfil profesional para responder a las demandas de la organización.

Ahora bien, debemos hacer una doble distinción. Por un lado, vamos a referirnos al régimen jurídico de las viviendas militares. Por otro a los llamados "pabellones de cargo".

\section{A) Viviendas Militares.}

Las viviendas militares, son aquellas que son susceptibles de ser adjudicadas a militares que cambian de destino, en casos singulares derivados de motivos de operatividad, funcionalidad o seguridad.

En algunos casos esa adjudicación, responderá a razones basadas en la particularidad del puesto que se ocupe y la vivienda militar será inherente al destino; en

\footnotetext{
${ }^{113}$ Vid. SSTC 76/1992, de 14 de mayo y 199/1998, de 13 de octubre.

${ }^{114}$ Así lo ha declarado constantemente la jurisprudencia del TC exigiendo bien un pronunciamiento judicial previo acordando el desalojo, que haría innecesaria una duplicidad de resoluciones judiciales (SSTC 160/1991, de 18 de julio, FJ 9 y 92/2002, de 22 de abril, FJ 3, entre otras), bien la autorización judicial en los supuestos en los que no ha existido resolución judicial previa (SSTC 144/1987, de 23 de septiembre, FJ 2; 76/1992, de 14 de mayo, FJ 3 y 139/2004, de 13 de septiembre, FJ 2, entre otras muchas).
} 
otros, serán razones objetivas por las características de determinadas viviendas las que aconsejaran su adjudicación, que se producirá en función de las cargas familiares, tiempo de servicios, destinos, entre otras condiciones especificas en que pudieran verse inmersos los posibles usuarios.

Resulta interesante destacar, que este régimen especial de aplicación a las viviendas militares quedará excluido del régimen general de la Ley 29/1994, de 24 de noviembre, de Arrendamientos Urbanos.

Son pues viviendas militares, aquellas cuya titularidad o administración corresponde al Instituto para la Vivienda de las Fuerzas Armadas y a los Cuarteles Generales de los Ejércitos, con excepción de los pabellones de cargo, a los que nos referiremos a continuación.

La especialidad del régimen jurídico de estas viviendas militares, radica en que son facilitadas al militar en arrendamiento especial y se encuentran localizadas dentro de bases, acuartelamientos, edificios o establecimientos militares o en zonas especificas en las que resulte necesario disponer de viviendas para el personal destinado en las mismas.

La contraprestación por el uso de las viviendas militares y plazas de aparcamiento consistirá en el abono de los correspondientes cánones mensuales o, en su caso, tasas cuya cuantía será fijada por el Ministro de Defensa. Una vez fijada, será actualizada cada año mediante la aplicación del índice de precios al consumo correspondiente al ejercicio económico anterior. ${ }^{115}$

Reglamentariamente, se establecen los derechos y obligaciones derivados de la adjudicación, en particular los relativos a las obras de mantenimiento, reparación y conservación de los edificios y viviendas y sus servicios comunes que serán de cuenta y cargo del Instituto de Vivienda, Infraestructura y Equipamiento de la Defensa (INVIED), salvo los deterioros que por falta de diligencia o mal uso sean imputables a los usuarios, si bien, los servicios individualizados o susceptibles de medición por contador y los tributos que los graven, serán en todo caso, sufragados por dichos usuarios.

Finalmente, añadiremos que el derecho de uso de las viviendas militares cesará por causas tales como el cambio en la situación administrativa que otorgó el derecho al uso de la vivienda, cambio de destino cuando implique cambio de localidad o área geográfica, cambio de destino cuando la vivienda esté vinculada al citado destino, fallecimiento del militar o perdida de la condición de militar de carrera o de militar profesional de tropa y marinería.

Sobre este tipo de alojamientos, se ha pronunciado el TEDH en su STEDH de 27 de abril de 1999, caso J.L.S. contra España. El asunto, trata de un militar que firmó ante el patronato de casas militares del Ejército de Tierra un documento administrativo de adjudicación de un alojamiento especial y obtuvo así el uso de una vivienda en Madrid.

En 1989 el demandante solicitó su paso a la reserva transitoria y como consecuencia del Real Decreto 1751/1990 de 20 de diciembre, a través del cual se creó el Instituto de la Vivienda de las FAS (antiguo INVIFAS), se suprimieron los patronatos de casas militares y se contempló que ciertos militares en situación de reserva

\footnotetext{
${ }^{115}$ En el caso de las viviendas militares dicho canon o tasa se establecerá atendiendo a los parámetros de localidad, superficie, ubicación, estado dotacional y tienen la naturaleza de precios públicos.
} 
transitoria, devolvieran sus alojamientos militares al Estado antes del 1 de enero de 1992.

Pues bien, el 10 de noviembre de 1992, el director general del INVIFAS informó al demandante de que debió haber devuelto su alojamiento antes del 1 de enero de 1992.

El 16 de diciembre de 1993, el demandante fue invitado a abandonar el alojamiento en un plazo de dos meses, orden que sería ejecutada, llegado el caso, a través de un proceso de desalojo.

A raíz del procedimiento administrativo incoado por el INVIFAS en contra del demandante, éste último fue apremiado a abandonar el alojamiento en una sentencia fechada el 6 de febrero de 1995 y firmada por el Secretario de Estado de la Administración Militar.

Tras varios tramites y procedimientos judiciales, el demandante presentó entonces ante el Tribunal Constitucional un recurso de amparo y en su sentencia fechada el 3 de noviembre de 1997, la Alta Instancia rechazó el recurso por considerarlo carente de fundamento constitucional. Fue entonces, cuando el militar, acudió al TEDH, que en la sentencia que comentamos, destacó que el demandante se avino a utilizar el alojamiento «en su calidad de militar» y a un precio muy ventajoso, comparado con los alquileres privados. No firmó un arrendamiento sino un «documento administrativo de adjudicación de alojamiento especial» ante el patronato de casas militares y no podía pretender siquiera que la utilización de su alojamiento pudiera compararse a un contrato de derecho privado.

El Tribunal destaca que esta política de concesión de alojamientos se basaba en la dificultad y la necesidad para los militares de encontrar alojamientos adecuados durante sus frecuentes traslados profesionales. Recuerda que el derecho a ocupar una residencia determinada, de la que no es propietario, no constituye un «bien» en el sentido del art. 1 del Protocolo núm. 1 del Convenio.

Además, autorizar a un «usuario» como el demandante, que ni siquiera tiene la categoría de arrendatario, a mantenerse indefinidamente en un alojamiento propiedad del Estado supondría, para el Estado en cuestión un obstáculo en el ejercicio del deber de las autoridades de administrar los bienes del mismo de acuerdo con las exigencias de la Constitución y de las leyes.

En la STS de 22 de abril de 1991 de la Sala Quinta ${ }^{116}$ el Tribunal realizó un estudio de la clasificación de domicilio establecida en la Orden 76/1986, de 22 de septiembre, por la que el Ministro de Defensa dictó la normativa reguladora de las viviendas oficiales de la Armada, estableciendo tres categorías:

I. Viviendas de representación: asignadas a los mandos y autoridades militares que, por razón de su cargo, las deben utilizar obligatoriamente, mientras lo desempeñan, como domicilio oficial y de representación social.

II. Viviendas de servicio: asignadas a determinados miembros de las Fuerzas Armadas que, en atención a su destino, se considera que deben vivir en el interior o proximidad de una dependencia, por lo que su ocupación es obligatoria mientras se permanezca en ese destino.

\footnotetext{
${ }^{116}$ En esta sentencia el Tribunal Supremo resolvió un recurso contencioso-disciplinario preferente y sumario. En ella no se analiza ningún tipo de vulneración del derecho a la intimidad domiciliaria, puesto que ello no se deduce de los antecedentes de hecho; no obstante nos interesa porque realiza una clasificación del tipo de viviendas militares y de la consideración que merecen.
} 
III. Viviendas disponibles: adjudicadas a aquellos que las soliciten por haber sido destinados a una unidad y no disponer de vivienda de su propiedad en la localidad donde radique el destino.

Según el Tribunal, las dos primeras: "Aún estando destinadas directamente a un uso particular, que es propio de todo hogar familiar, cumplen también una función relacionada con el servicio", siendo por tanto consideradas como material afecto al servicio de las FAS o de sus miembros, cosa que no ocurre con las denominadas “disponibles", cuya existencia responde a una necesidad asistencial.

En esta sentencia, el recurrente es sancionado como autor de la falta disciplinaria consistente en: "Utilizar para usos particulares medios o recursos de carácter oficial o facilitarlos a un tercero, todo ello cuando no constituya delito", por no haber desalojado la vivienda oficial que ocupaba tras su pase a la situación de reserva, incumpliendo el requerimiento de desalojo.

La Sala $5^{a}$ señala que la calificación de oficial de una vivienda no es suficiente para que se convierta a todos los efectos en medios o recursos de carácter oficial, por lo que: "En principio, toda vivienda construida o habilitada para que en ella habite un militar con su familia, está destinada a un uso particular, porque no cabe un ámbito más particular o privado que aquel en el que la persona satisface sus necesidades de vida doméstica”.

En este caso, la conducta del recurrente se hizo acreedora de sanción porque la negativa al desalojo supuso una actitud de desobediencia de la orden dictada por la autoridad competente, incurriendo así en un ilícito disciplinario.

De acuerdo con este razonamiento del Tribunal Supremo, podemos considerar que cuando estemos ante una vivienda de titularidad militar pero cedida, por cualquier razón (ya sea por el puesto desempeñado, por necesidades del servicio o para facilitar el alojamiento), a un miembro de las Fuerzas Armadas para que sirva de alojamiento, tendrá la consideración de domicilio, protegido a todos los efectos con las mismas garantías y por la misma regulación que para el resto de ciudadanos.

B) Pabellones de cargo.

Se denominan pabellones de cargo los inmuebles que se destinan para ser utilizados como domicilio oficial, y en su caso de representación social, por autoridades militares del Ministerio de Defensa atendiendo, fundamentalmente, a la necesidad de una presencia continuada en el interior, o en las proximidades de la instalación militar, donde el militar beneficiario presta su servicio.

Normalmente, estas viviendas se encontrarán ubicadas en el interior de bases, acuartelamientos, edificios y establecimientos militares, aunque con carácter excepcional, cabría la posibilidad de designar como tales, y en su defecto, otras viviendas. Al igual que ocurra con las viviendas militares, será responsabilidad del INVIED la administración, mantenimiento, conservación y rehabilitación de los inmuebles que se califiquen como pabellones de cargo.

Resulta significativo que la ocupación de los pabellones de cargo sea obligatoria y deba realizarse en el plazo de un mes desde su adjudicación al titular, si bien, con carácter excepcional y por razones extraordinarias debidamente justificadas, las autoridades militares competentes, y dentro de su ámbito competencial, podrán conceder dispensa a los titulares de los pabellones de cargo para no ocuparlos, así como para prorrogar el plazo para su ocupación hasta un máximo de dos meses desde la adjudicación. 
Son características propias de este tipo de alojamiento militar las siguientes: ${ }^{117}$

- $\quad$ Su uso es gratuito.

- Están dotados del mobiliario, y en su caso, medios informáticos, telemáticos, telefónicos y enseres que determinen, en su ámbito competencial, las autoridades militares competentes.

- $\quad$ Correrán por cuenta del Ministerio de Defensa los gastos derivados del mantenimiento, conservación y rehabilitación.

- $\quad$ También serán de cuenta del Ministerio los gastos de agua, luz, gas, comunidad e impuestos, de los pabellones de cargo si estuvieran sitos fuera del acuartelamiento.

- $\quad$ La dotación, reposición y reparación del mobiliario, medios informáticos, telemáticos, telefónicos y enseres así como los gastos derivados del uso de los mismos, las reparaciones de desperfectos, deterioros y averías producidas en los pabellones de cargo y zonas comunes del inmueble, igualmente serán asumidos por el Ministerio.

VI. Camarotes de buques, submarinos de la Armada y aeronaves militares.

Con carácter general, las embarcaciones, ${ }^{118}$ no constituyen domicilio a efectos constitucionales, salvo aquéllas partes destinadas específicamente a los camarotes, dormitorios de la tripulación o pasajeros, u otros lugares reservados para una persona o grupo de personas.

Y ello aunque se tratase de un yate o embarcación de recreo, en el que podría predominar el aspecto de lugar destinado a la vida personal y familiar, íntima en todo caso; pero si dicha embarcación fuera utilizada sólo para el transporte de mercancías, faltaría la razón de ser de la inviolabilidad proclamada en el artículo 18.2 CE.

Siendo así todo lo anteriormente expuesto, tenemos que tener en cuenta, la distinción jurisprudencial ${ }^{119}$ que se efectúa entre las distintas zonas del barco y por extensión de la aeronave, en orden a determinar los lugares objeto de protección constitucional.

En un primer momento, podríamos colegir, que la hipotética afectación al derecho a la inviolabilidad del domicilio podría producirse exclusivamente en aquéllas partes del barco o aeronave, que por sus características fueran destinadas a uso habitacional y aptas para el desenvolvimiento de la vida personal.

Recientemente, el TS Sala $2^{\mathrm{a}}$ en su sentencia de 6 de febrero de 2014 se ha pronunciado sobre la materia indicando que:

"No existía entonces, ni tampoco ahora, ninguna constancia de que el barco Serrano Segundo, destinado a la pesca, constituyera el domicilio de persona alguna, menos aún en la cubierta, en la bodega o en el puente de mando, que fueron las zonas a las que accedieron los agentes del SVA con anterioridad a la autorización judicial. Ello no es contradictorio con el hecho de que procedieran a solicitar tal autorización, pues un registro completo de la embarcación debiera incluir la zona de los camarotes o similares que pudieran estar destinados, al menos en algún momento de la navegación o uso del barco, a la realización de actos propios de la privacidad individual, encontrando, pues, la protección constitucional correspondiente al domicilio”. ${ }^{120}$

\footnotetext{
${ }^{117}$ Vide. ORDEN DEFENSA/3242/2005, de 10 de octubre, por la que se regulan los pabellones de cargo del Ministerio de Defensa.

${ }^{118}$ Vid. STS 151/2006, de 20 de febrero.

${ }^{119}$ Vide. SSTS 624/2002, de 10 de abril y 1200/1998, de 9 de octubre.

${ }^{120}$ Vid. FJ 1 STS 16 de febrero de 2014.
} 
Una embarcación puede constituir la morada de una o varias personas cuando la utilicen como reducto de su vida privada, pues sin duda en ocasiones están construidas de forma que algunas de sus dependencias, como los camarotes, resultan aptas para que en las mismas se desarrollen conductas o actividades propias de áreas de privacidad, pero resulta dificultoso extender el concepto de domicilio en todo caso a otras zonas de aquélla.

Nada impide, sino más bien lo contrario según la experiencia, que determinadas zonas del barco se destinen específicamente a otros fines distintos de los propios del domicilio, como puede ocurrir con la cubierta, utilizada en las maniobras náuticas como lugar de esparcimiento, o las bodegas, utilizadas exclusivamente para la carga, o la zona de máquinas y en estos casos no se puede extender indiscriminadamente a estas zonas del barco la misma protección que la CE otorga al domicilio, pues no pueden entenderse aptas con carácter general para la vida privada. ${ }^{121}$

En el barco existen áreas propias y reservadas al ejercicio de la intimidad personal, que son precisamente las únicas protegidas por el derecho fundamental consagrado en el artículo 18.2 de la Constitución.

Las demás zonas de la embarcación, destinadas a otras finalidades, no gozan de la protección que la Constitución dispensa al domicilio, aunque se trate de lugares respecto de los cuales su titular pueda excluir válidamente la presencia de terceros:

"Las zonas a las que accedieron los agentes no estaban protegidas de la misma forma que si fueran domicilio o sus dependencias, pues es claro que tanto la cubierta del barco pesquero como su bodega no reúnen condiciones para entender que se utilizan como reducto de la vida privada de los tripulantes. No siendo necesaria, por lo tanto, autorización judicial derivada del artículo 18 de la Constitución (...)”. ${ }^{122}$

En el caso de los buques de guerra y aeronaves militares, ${ }^{123}$ ha de tenerse en cuenta, sobre todo en navegaciones de larga duración, con motivo de la participación de aquéllos en maniobras o en operaciones de mantenimiento de la paz, que constituyen, además del lugar de trabajo en el que la dotación ejerce su actividad profesional, el espacio en el que durante los periodos de inactividad o descanso, y en las áreas destinadas al alojamiento, podría llegar a desarrollarse la vida privada, así pues, hemos de analizar si los aludidos espacios resultan aptos para su consideración como domicilio a efectos constitucionales.

En los supuestos en que los camarotes o alojamientos de los buques de guerra, o aeronaves militares, son compartidos obligatoriamente con un extraño, lo cual ocurre en la mayoría de aquéllos dado que, como regla general, sólo tendrán camarote individual, el comandante del barco y el segundo comandante, no es posible que el individuo desenvuelva en ellos la vida personal, es decir, su libertad más íntima, fuera de los usos y convencionalismos sociales; de ahí que dichos espacios, según nuestra opinión, no son domicilio desde el punto de vista constitucional.

Por el contrario, sí constituyen domicilio los alojamientos ubicados en buques de guerra o aeronaves militares, ocupados por una sola persona, dado que en su interior, y aún con las limitaciones de uso que pudieran derivarse de las normas de régimen

\footnotetext{
${ }^{121}$ Vide. STS n ${ }^{0}$ 544/2011 y STS n ${ }^{\circ}$ 624/2002.

${ }^{122}$ Vide. FJ $2^{\circ}$ STS 6 de febrero de 2014 y STS 9 de octubre de 1998.

${ }^{123}$ Sobre la consideración de domicilio de buques, submarinos y aeronaves militares, puede consultarse el estudio de Pascual Sarriá, F.L.: «La entrada y registro en instalaciones militares», Jornadas sobre jurisdicción militar. CGPJ. 2007, pp. 157.
} 
interior, pueden realizarse actividades propias de la vida íntima y personal, sin la cortapisa de la presencia de un extraño, por lo que, según nuestra opinión, estos lugares gozan de protección constitucional. ${ }^{124}$

Otro tanto de lo mismo podemos añadir respecto de los camarotes habilitados en los submarinos de la Armada para el descanso de los marineros y resto del personal. No pueden ser considerados domicilio, a los efectos de protección constitucional que estamos analizando con éste derecho fundamental, toda vez que dichos lugares no resultan aptos para el desarrollo de la intimidad personal, tratándose de alojamientos asignados en los que llega a compartirse no solo el camarote, sino incluso, y por períodos horarios, la misma litera, de la misma manera que, por razones de espacio, se comparte la taquilla asignada. Al igual que ocurre con los camarotes de los buques de guerra, no podemos considerar que dichos habitáculos constituyan domicilio, al no ser lugares en los que los marineros puedan desarrollar un mínimo de vida privada, si bien limitándolo a aquellos casos en los que éstos sean aptos para el ejercicio de la intimidad personal, circunstancia ésta que no se da en los submarinos militares.

Concluimos, trayendo a colación y a los efectos que nos ocupan, el contenido del artículo 185 de la Ley Procesal Militar:

"Para proceder a la entrada y registro en (...) buques o aeronaves militares de los Ejércitos deberá preceder aviso a la autoridad militar o jefe de aquella, a fin de que preste el debido auxilio, a no ser que el imputado o denunciado sea dicho jefe, en cuyo caso, a los mismos efectos, la comunicación se hará a su superior jerárquico inmediato, salvo cuando la investigación de los hechos no lo permita”. Llama la atención que para proceder a realizar una entrada y registro en buques y aeronaves de los Ejércitos, es necesario dirigir solicitud de colaboración al comandante del buque o al comandante de la aeronave, distando el precepto transcrito de su homónimo de la LECrim, al considerar el artículo 547.4 los buques del Estado, como un lugar público, no siéndoles de aplicación ningún requisito especial.

Nos encontramos, a primera vista, ante una importante singularidad respecto a la regulación del artículo 546 de la LECrim, toda vez que los "edificios y dependencias militares", no son sino una clase de "edificios públicos"; y en la normativa procesal común no se establece la necesidad de ningún tipo de previa comunicación al encargado de dichos edificios, pudiendo la autoridad judicial "decretar la entrada y registro, de día o de noche”, sin más trámite. No advertimos más justificación a esta comunicación previa que la derivada de las especiales funciones que, en orden a la defensa nacional y cumplimiento de las misiones, tienen constitucionalmente encomendadas las Fuerzas Armadas.

Y ello debido al material sensible que se maneja, las zonas de acceso prohibido por razones estratégicas, de seguridad nacional, de la OTAN o las medidas de seguridad perimetrales e internas de las unidades y bases militares con centinelas armados con la consigna de impedir el acceso al recinto de personal que no se encuentre debidamente autorizado por el mando superior.

\footnotetext{
${ }^{124}$ Avala la posición que mantenemos respecto a los reseñados lugares, la doctrina que puede extraerse de la ilustrativa STS de 18 de octubre de 2006, cuando declara que: "Ningún problema se plantea para reconocer la condición de domicilio a un camarote de un barco como un lugar separado donde uno de sus tripulantes o viajeros se independiza de los demás que comparten las zonas comunes para desarrollar su privacidad en la medida que lo desee... como se reconoce en la STS núm. 1200/1998, de 9 de octubre, en el barco existen áreas propias y reservadas al ejercicio de la intimidad personal, que son precisamente las únicas protegidas por el derecho fundamental consagrado en el artículo 18.2 de la Constitución”. (Ponente Colmenero Menéndez de Luarca).
} 
Ahora bien, la necesaria comunicación anticipando la entrada no podrá ser entendida, en ningún caso, y en nuestra opinión, como una limitación a la actuación de la autoridad judicial, sino que por el contrario, estaremos ante una vía que permita agilizar las actuaciones a practicar, removiendo los obstáculos innecesarios, que en aras a la seguridad y custodia de locales, se pudieran producir, colaborando y facilitando en todo momento la labor judicial.

De otro lado, esta comunicación previa servirá para que, al acceder al recinto militar, a zonas de seguridad o restringidas con armamento y material clasificado por razones de seguridad, este no quede a la vista si no es el objeto de las actuaciones, o no ha sido desclasificado previamente.

Consideramos que en otro caso no podrá el jefe de la unidad obstaculizar la labor judicial, y mucho menos negar el acceso al buque o aeronave, toda vez que en dicho supuesto incurriría, bien en un "Delito contra la Administración de Justicia Militar”, previsto en el artículo 187 del Código Penal Militar; bien en un delito de “Denegación de auxilio a la justicia”, previsto y penado en el artículo 412 del Código Penal.

Cosa distinta es que nos cuestionemos cuál sería el alcance del hecho de que se hubiera practicado la diligencia de entrada y registro sin el previo aviso a las autoridades o jefes de los correspondientes lugares militares.

En nuestra opinión, no pasaría de ser una mera irregularidad procesal, que no tendría efecto alguno en la propia diligencia, dado que el citado aviso, que como señala el artículo 185 de la Ley Procesal Militar, solamente persigue como finalidad, la prestación de auxilio a la autoridad judicial, no puede convertirse, precisamente por un excesivo rigor en cuanto a su exigencia, en una cortapisa o limitación a la actuación judicial que, además, resultaría contraria a la pretendida finalidad de colaboración y facilitamiento de la labor de aquélla.

La norma analizada, en su último inciso, excluye la necesidad de esta comunicación previa en aquellos supuestos en los que el juez considere que la misma puede perjudicar al objeto de la investigación, no haciéndose en este supuesto necesaria la misma; ni tampoco cuando los mandos militares a los que se les debe de realizar la comunicación sean los denunciados o imputados.

\section{Tiendas de campaña, contenedores o barracones.}

La determinación de qué se haya de entender por habitáculo o morada ha sido una tarea de la doctrina científica y jurisprudencial, en la que se ha llevado a cabo una interpretación ajustada al espíritu de nuestra Constitución y de la propia Ley de Enjuiciamiento Criminal, estimando que constituye morada cualquier lugar, cualquiera que sea su condición y características, donde viva una persona o una familia, sea domicilio o residencia, estable o transitoria, incluidas las chabolas, tiendas de campaña, roulottes, etc., comprendidas las habitaciones de un hotel, residencia u hospedería en la que se viva. Por ello, el destinatario de una diligencia de entrada y registro domiciliario, será quien sea poseedor del piso o vivienda, incluso cuando la posesión la tenga como precarista. ${ }^{125}$

125 Cfr.: Pascual Sarría, F.L.: «La entrada y registro en las instalaciones militares»,...op, cit, pp. 156 y 157.; Climent Duran, C.: La prueba penal. Tomo II, 2a ed. Tirant lo Blanch. Valencia. 2005, pp.11301133.; Magro Servet, V.: «Casuística sobre el concepto penal de domicilio en la diligencia de entrada y registro», La Ley, fascículo 2002-2, pp.1770; Gómez Tomillo, M. (Dir.): Comentarios al Código Penal, 
En el ámbito militar, tal y como señalamos al inicio, resulta frecuente que, para el alojamiento de las tropas que se desplazan para la realización de ejercicios, maniobras u operaciones militares, dentro y fuera del territorio nacional, se habiliten tiendas de campaña, contenedores habitables o barracones, en los que pernoctará, por grupos, el personal militar y desarrollará un mínimo de intimidad.

Estos habitáculos propiedad del Estado se ponen a disposición de los militares durante el tiempo en que desarrollan los ejercicios u operación, con la única finalidad de dotarles de un lugar para el descanso, desarrollando su vida en común con el resto de miembros del contingente (comida, aseo, ejercicio, ocio...), y con una dedicación permanente al servicio que desempeñan durante las 24 horas del día y todos los días que dure la misión, por lo que nos hallaremos ante un ámbito de privacidad menor que el de los dormitorios de las unidades, en el que no cabe apenas un resquicio para la intimidad de los usuarios que forman parte de dichos contingentes, quiénes asumen la limitación de su intimidad en aras al cumplimiento de la misión encomendada.

Dichos "alojamientos" son asignados a discreción del mando, en función del sexo y empleo, no pudiendo cambiarse, ni elegir a los compañeros con quiénes se comparte, no admiten la tenencia de mobiliario personal o de efectos que no sean los propios del servicio, por lo que la entrada y registro en los mismos se podrá realizar por el jefe del contingente, sin ninguna prevención, al tratarse de instalaciones militares que no gozan de la condición de domicilio, no vulnerándose con ello la intimidad del militar alojado. $^{126}$

La STS de 30 de abril de 1996, por vía de obiter dictum, afirma que: “Quizás podría considerarse como domicilio a la tienda de campaña en la que, con unas condiciones mínimas se ejercitase una vivencia íntima". ${ }^{127}$

Y es que, como declaran las SSTS de 20 de noviembre de 1995 y 19 de mayo de 1999 de acuerdo con el artículo 8.1 del Convenio Europeo de Roma de 1950 y de acuerdo también con el artículo 17 del Pacto Internacional de Nueva York: "Sirve para cobijar el concepto de domicilio cualquier local por humilde y precaria que sea la construcción en donde viva la persona, las personas o la familia, incluso en concepto de residencia temporal, desde la roulotte, la tienda de campaña o la chabola, hasta el mayor de los palacios. Cualquier ámbito espacial limitado, que el sujeto escoge y elige y que por lógica ha de quedar exento o inmune de las agresiones exteriores, sea un particular, sea la autoridad".

Luego, a la vista de los pronunciamientos jurisprudenciales esgrimidos, llegamos a la conclusión de que las tiendas de campaña si bien, en principio, podrían llegar a constituir “domicilio” susceptible de protección vía artículo 18.2 de nuestra CE, por sus especiales características en el ámbito militar, cesan en tal condición, toda vez que no reúnen las condiciones de intimidad mínimas exigidas a tal fin, quedando, por ende, el mando militar legitimado a la hora de efectuar inspecciones en las mismas sin

Lex Nova. Valladolid. 2010, pp. 814 y ss.; Queralt Jiménez, J.J.: Derecho Penal Español, Parte Especial. Atelier. Barcelona, $5^{\mathrm{a}}$ ed., 2008, pp. 252.; Corcoy Bidasolo, M.: Derecho Penal, Parte Especial, doctrina y jurisprudencia con casos solucionados. Tomo I. Tirant lo Blanch. Valencia. 2011, pp. 283 y ss. Véase también, SSTS de 16 de septiembre de 1993; 8 de julio de 1994 y SSTS de 30 de junio de 1996 y de 18 de enero de 2001.

${ }^{126}$ Vid. STS Sala Segunda, de 20 de noviembre de 1995 (Ponente Vega Ruiz); STS 30 de abril de1996 (Ponente Vega Ruiz); STS 23 de septiembre de 1997 (Ponente Delgado García); o la STS de 18 de noviembre de 2005 (Ponente Ramos Gancedo).

${ }^{127}$ En el mismo sentido se pronuncian las SSTS 8 de julio de 1994; 15 de febrero de 1997 y 23 de septiembre de 1997. 
ningún tipo de prevención previa, en aras al mantenimiento de la disciplina o en prevención de ilícitos disciplinarios o penales.

Otro tanto de lo mismo añadimos respecto de los barracones o contenedores, pues en este caso, con más motivo aún, en nuestra opinión, y por sus especiales características, están pensados y son destinados al alojamiento de una pluralidad de militares, reduciéndose al mínimo, si no excluyéndose, cualquier posibilidad de desarrollar vida íntima en ellos.

\section{Alojamientos logísticos habilitados para la tropa y marinería.}

Nos referimos ahora a otro supuesto interesante como objeto de estudio, a la hora de delimitar el concepto de domicilio y su protección constitucional como tal en el ámbito castrense. Se trata de los alojamientos logísticos, o lo que es lo mismo, alojamientos habilitados para el personal militar de tropa y marinería en el interior de las unidades, centros $\mathrm{y}$ organismos militares. ¿Pueden ser considerados domicilio?¿Pueden ser estos objeto de entrada y registro por acuerdo de la autoridad militar?.

Debemos partir de las características propias de este tipo de habitáculos, pues sus singularidades hacen que se difumine, en gran medida, su posible consideración como domicilio constitucionalmente protegido a los efectos que merece la protección de la intimidad de cualquier ciudadano, y en el caso que nos ocupa, de quiénes en ellos residen.

Destacamos las características más relevantes:

1. Se trata de alojamientos de titularidad estatal (Ministerio de Defensa), puestos a disposición del personal de tropa y marinería destinado en la unidad para facilitar su alojamiento y por cuyo uso no se abona canon alguno. ${ }^{128}$

2. Se encuentran ubicados en el interior de las unidades, formando parte de sus instalaciones y con sometimiento al régimen de gobierno interior de las mismas, debiendo someterse en su utilización a las normas que garantizan el orden, gobierno y disciplina propios de la instalación militar en la que se integran (conservación, limpieza, horario, enseres a introducir, mobiliario, seguridad, disciplina...). ${ }^{129}$

\footnotetext{
${ }^{128}$ Hemos de señalar, que actualmente y con motivo de la situación de crisis económica, con la contención del gasto y la disminución de las partidas presupuestarias, el Ministerio de Defensa se ha visto obligado a fijar un canon a los usuarios, por la prestación de los servicios que se dan en este tipo de alojamientos, con el fin de que los referidos servicios, puedan ser facilitados de acuerdo a las características propias de los mismos. Así, por ejemplo en el ámbito de la Armada, la Instrucción 630/06141/2012, de 30 de marzo, del Almirante Jefe de Personal, sobre residencias de la Armada, establece unos cánones por persona y día para los usuarios de los alojamientos logísticos de la Armada, que oscilan en función del empleo militar (Tropa, Suboficial, Oficial o General Oficial) entre 0.50 euros y 3 euros, que se harán efectivos a los órganos gestores de los alojamientos logísticos de la Armada. Los importes recaudados por este concepto se ingresarán en el Tesoro para generar los créditos correspondientes. A pesar de ésta circunstancia, entendemos que se tratan de cantidades simbólicas, muy por debajo del precio de mercado y que por tanto en nada afecta a las características y naturaleza de éste tipo de alojamientos.

${ }^{129}$ Por ejemplo la Instrucción Permanente de Organización núm. 001/2014, de 27 de febrero, del ALMIRANTE JEFE DE PERSONAL, por la que se establecen las normas generales de régimen interior de los alojamientos logísticos de la Armada, establece que: "Los residentes no realizarán actividades molestas ni producirán ruidos que puedan perturbar el descanso del resto de los usuarios. No está

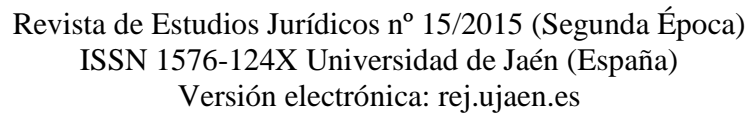


3. No suelen ser habitaciones de uso individual, sino que normalmente son camaretas compartidas por un mínimo de 2 ó 3 militares.

4. La asignación al personal de la habitación que debe ocupar es decisión del mando militar, no pudiendo escoger los alojados ni la habitación, ni los otros militares con quiénes la comparte, pudiendo ser obligado a compartir la camareta incluso con quién no quiera, al ser una decisión voluntaria residir en ella o fuera de la unidad. ${ }^{130}$

5. El alojarse en dichos módulos es una decisión libre y voluntaria, por lo que quien opte por residir en ellos, elige someterse al régimen de vida y funcionamiento establecido para los mismos, entre los que se encuentran las revistas de policía, y la necesidad de mantener el orden y la disciplina en su interior; así como someterse al horario de entrada y salida en la unidad y a las normas de seguridad del acuartelamiento donde se ubique.

6. No puede alojarse en las mismas nadie que no esté debidamente autorizado por el mando competente, debiendo tratarse siempre de personal de las FAS; y sin que el residente pueda introducir a ninguna persona en su camarote, ni permitir que pernocte nadie aunque se trate de su familia o pareja. ${ }^{131}$

Estos alojamientos, vienen regidos por los llamados "libros de normas de régimen interior", cuyo contenido viene constituido por el régimen de ocupación, administración, limpieza, régimen de vida, horarios y causas de desalojo, determinando una serie de obligaciones, sobre la base de la voluntariedad de los usuarios que solicitan dichos alojamientos.

La finalidad principal de estos habitáculos es la de apoyar la movilidad geográfica de los componentes del Ejército que se desplacen o precisen alojamiento por razones de servicio, atendiendo en primer lugar las necesidades del personal que con motivo de la asignación de un nuevo destino o comisión de servicio sin derecho a indemnización, se encuentre desplazado en una localidad distinta a la habitual de residencia con su familia.

Llegados a este punto, traemos de nuevo a colación, el derecho a la intimidad del militar, que tantas veces hemos vinculado al domicilio, ya que nos surge la duda, de si

permitido realizar cambios ni modificaciones en la decoración de las habitaciones que supongan deterioro de su estructura. Con el fin de evitar sobrecargas eléctricas y posibles riesgos de incendio se prohíbe instalar sistemas eléctricos supletorios, usar hornillos, planchas de cocina u otros aparatos eléctricos diferentes de los ya existentes en la habitación. En las habitaciones no está autorizado el almacenamiento de materiales tóxicos ni inflamables. Tampoco se permitirá la existencia de alimentos perecederos".

${ }^{130}$ La Instrucción Permanente de Organización núm. 001/2014, de 27 de febrero, del ALMIRANTE JEFE DE PERSONAL, por la que se establecen las normas generales de régimen interior de los alojamientos logísticos de la Armada, establece que: "La asignación de habitación en el alojamientos logísticos de la Armada supone la plena aceptación de las normas e instrucciones de régimen interior en vigor,(...) y está obligado al uso y ocupación del alojamiento asignado, no pudiendo cambiar de habitación sin autorización previa del administrador”.

${ }^{131}$ Igualmente, utilizamos como ejemplo la Instrucción Permanente de Organización núm. 001/2014, de 27 de febrero, del ALMIRANTE JEFE DE PERSONAL, por la que se establecen las normas generales de régimen interior de los alojamientos logísticos de la Armada, que al respecto establece que: "No está permitido el acceso a la zona de alojamientos al personal no residente. Las visitas serán recibidas en los espacios que a tal efecto se dispongan, tampoco se autoriza la permanencia del usuario en habitación distinta de la asignada”.

Revista de Estudios Jurídicos nº 15/2015 (Segunda Época)

ISSN 1576-124X Universidad de Jaén (España)

Versión electrónica: rej.ujaen.es 
puede llegar a ser compatible con el régimen interno de vida y funcionamiento de este tipo de alojamientos.

Entendemos, que la intimidad debe quedar garantizada, si bien con el límite de que no afecte al orden, gobierno y disciplina, imprescindibles para el funcionamiento de una instalación castrense.

Los militares alojados en los dormitorios situados dentro de las unidades militares, aunque sea de manera eventual, deberán gozar de un mínimo de intimidad, por lo que la entrada y registro o revista, deberán de realizarse tan solo en la medida en que resulten necesarias para los fines señalados, así lo ha reconocido el propio TS (Sala Segunda), entre otras, en la STS de 26 de enero de 1995 (Ponente Cotto Marques de Prado), en la que se reconoce la necesidad de respetar las normas de buen gobierno y orden del estamento castrense, pues se vería resquebrajada la disciplina y seguridad de la propia unidad, si no se admitieran estas "revistas". ${ }^{132}$

En principio, y a la vista de todo lo anteriormente argumentado, podemos concluir que los llamados “módulos de alojamiento", por sus especiales características, no pueden gozar de la misma protección que el domicilio. Y ello, porque entendemos, que dichos alojamientos no resultan idóneos para desarrollar las actividades elementales de la vida privada, al no estar destinadas a dicho fin. No debemos olvidar, como se ha indicado anteriormente, que el alojamiento se comparte obligatoriamente, no se abona cargo alguno por residir (o resulta simbólico e insignificante) y no puede usarse o disponer de él con la libertad de quién está en su domicilio.

Este tipo de alojamiento tiene regulado y limitado su disfrute, por razones de disciplina, buen gobierno o seguridad, quedando prohibido el acceso a otras personas, introducir otro mobiliario, o diversas actividades a desarrollar en su interior (queda prohibido el consumo de alcohol, drogas tóxicas o estupefacientes, ruidos molestos, el juego cuando no sea mero pasatiempo, hacer agujeros en la pared, el mantenimiento de relaciones sexuales, las riñas o reyertas con compañeros, o la falta de respeto a los superiores, entre otras actividades, cuya realización se encuentra disciplinariamente sancionada).

Tampoco en nuestra opinión, puede desarrollarse la vida privada en las zonas comunes de los módulos de alojamiento (aseos, oficios y sala de visitas), y ello por la falta de aptitud de dichos espacios, dado su carácter común, para ejercitar en ellos, la vida personal y familiar.

Es precisamente por este motivo por el que entendemos que a diferencia de las residencias militares, las residencias de estudiantes y las residencias de descanso, no

\footnotetext{
${ }^{132}$ Vide. STS de 26 de enero de 1995 FJ 3: "En modo alguno puede estimarse que se atente contra la intimidad personal garantizada en el número 1 del artículo 18 de la Constitución Española por el hecho de practicarse en un establecimiento militar las revistas de las taquillas existentes en los dormitorios comunes a disposición de los soldados para guardar sus enseres, ya que ello viene reglamentariamente impuesto por las normas del buen gobierno y orden del estamento castrense, que vería resquebrajada en caso contrario la disciplina, e incluso la seguridad del propio acuartelamiento, si se permitiese que cada uno de cuantos en él se encontrasen prestando su servicio pudiera libremente campar por sus respetos; y, en segundo lugar, porque no siendo ciertamente un dormitorio común de un cuartel el domicilio a que se refiere el número 2 del precepto constitucional acabado de citar, es claro que no se ha violado tampoco el derecho que tal artículo confiere a toda persona a que no se entre ni registre su vivienda sin mediar su consentimiento o mandamiento judicial que lo autorice, por lo que procede, por ajustado a derecho, confirmar el fallo combatido". En el mismo sentido, véase las SSTS de 8 de octubre de 1999 (Ponente Moner Muñoz, FJ 1), y de 9 de junio de 2000 (Ponente Puerta Luis, FJ 2).
}

\author{
Revista de Estudios Jurídicos nº 15/2015 (Segunda Época) \\ ISSN 1576-124X Universidad de Jaén (España) \\ Versión electrónica: rej.ujaen.es
}


pueden considerarse este tipo de alojamientos “domicilio", es decir, las limitaciones de uso impuestas a los residentes de los dormitorios ubicados en los módulos de alojamiento, en nuestra opinión, impiden su consideración como tal, y lo entendemos así, aún cuando lo relevante desde un punto de vista constitucional, no es el hecho de que pudieran presentar numerosas limitaciones de uso, sino la posibilidad que existe en los mismos, de desarrollar la vida privada, que además exige la existencia de una serie de indicios que lo evidencien.

En este sentido, podemos indicar que el Tribunal Supremo ${ }^{133}$ ha configurado dichos indicios con una gran amplitud y afirma que las fotografías del usuario, el contrato de alquiler de la vivienda, una agenda con anotaciones personales y varios documentos de identidad en blanco, constituyen efectos que denotan la realización de la vida privada en el domicilio. Ahora bien, tal y como expusimos en renglones anteriores, eso no significa que el militar no goce de protección a su intimidad, toda vez que puede ejercitarla plenamente si no reside dentro del acuartelamiento.

Tampoco de lo dicho puede colegirse que las revistas o inspecciones de estos "módulos de alojamiento" se puedan realizar siempre que no resulten "arbitrarias o carentes de justificación”.

Pero ¿cuáles pueden ser los problemas jurídicos con relevancia constitucional, que pueden suponer en éste tipo de alojamientos, las inspecciones o revistas y la diligencia de entrada y registro?.

Para dar respuesta a la cuestión que acabamos de plantear debemos partir de una doble distinción que, a nuestro juicio, se hace necesaria toda vez que suele utilizarse de manera indistinta y como si de sinónimos se tratare en el ámbito castrense, los términos "revista o inspección” y “entrada y registro.”

Existe una diferencia fundamental entre las "revistas o inspecciones" y la “diligencia de entrada y registro”, que radica según nuestra opinión, tanto en las personas que pueden acordarlas, el mando militar y la autoridad judicial, respectivamente, como en la finalidad hacia la cual se hallan orientadas. Así, mientras que las primeras están encaminadas a verificar el grado de mantenimiento y conservación de las instalaciones y mobiliario, habiendo de atenderse en cuanto a la preservación del orden, a lo dispuesto en el reglamento de uso de los alojamientos, aprobado por el correspondiente órgano gestor, sin olvidar además, que lo que ocurra en el interior de los alojamientos logísticos, también puede afectar al buen orden de las bases, acuartelamientos o instalaciones en los que aquéllos se ubican; la diligencia de entrada y registro, tiene como finalidad, la investigación o descubrimiento de la posible comisión de un delito.

Las revistas o inspecciones sólo justificarían la entrada en un dormitorio de un alojamiento logístico para, conforme el Diccionario de la Real Academia de la Lengua, examinar, reconocer atentamente, el estado de las instalaciones, actividades estas que no comprenden la apertura de cajones, armarios cualesquiera que sea la denominación de estos, ubicados en aquél por el respeto debido al derecho a la privacidad de los convivientes y en definitiva al derecho a la intimidad que garantiza el artículo 18.1 CE, el cual implica la existencia de un ámbito propio y reservado frente a la acción y conocimiento de los demás, necesario, según las pautas de nuestra cultura, para mantener una calidad mínima de la vida humana. ${ }^{134}$

\footnotetext{
${ }^{133}$ Vide. STC 94/1999, de 31 de mayo.

${ }^{134}$ Vid. STC 196/2004, de 15 de noviembre y 25/2005, de 14 de febrero.

Revista de Estudios Jurídicos nº 15/2015 (Segunda Época)

ISSN 1576-124X Universidad de Jaén (España)

Versión electrónica: rej.ujaen.es 
Dicha intimidad, la otorga cuando menos una facultad negativa o de exclusión que impone a terceros el deber de abstención de intromisiones salvo que estén fundadas en una previsión legal que tenga justificación constitucional y que sea proporcionada o que exista un consentimiento eficaz que lo autorice. ${ }^{135}$ Dicho de otro modo, actualmente carece de soporte legal alguno, la realización de registros por el mando militar y ello aunque sea para prevenir o perseguir delitos o faltas disciplinarias.

Si existiesen indicios de la comisión de un delito será preceptivo el consentimiento del titular derecho a la inviolabilidad del domicilio para el acceso al dormitorio, o en su defecto, que el mando militar de cuenta a la autoridad judicial, (juez togado), para que autorizase la entrada y registro. ${ }^{136}$

En estas camaretas de alojamiento para la tropa, se podrán realizar aquellas entradas y registros que vayan dirigidos a comprobar el mantenimiento del buen orden, disciplina y seguridad, el estado de dichas instalaciones y de los enseres, pudiendo incluso, procederse al registro de taquillas, siempre que estas contengan elementos asignados al servicio, bastando para ello, si no media consentimiento de su titular, con que se realice con las garantías legalmente establecidas y por orden del jefe de la unidad.

Si, por el contrario, en dichos alojamientos se cede el uso de armarios o taquillas para guardar los efectos personales del militar allí alojado, este mobiliario no podrá ser abierto sin autorización judicial (juez togado militar), ante la sospecha de la comisión de un delito y con todas las garantías para proteger su intimidad contendidas en la Ley de Enjuiciamiento Criminal. En caso contrario la apertura de dichos armario o taquillas, además de vulnerar el derecho a la privacidad del militar, convertirían en prueba ilícita la que fuera así obtenida, que devendría inútil a los efectos de la comisión de un delito de naturaleza común o militar, careciendo de toda utilidad.

\section{A modo de conclusión.}

El estudio de los derechos fundamentales tenemos que reconocer que no es una materia novedosa, e incluso podríamos decir que su estudio técnico-jurídico es relativamente sencillo. Pero lo que aparentemente podía resultar ser conocido, y una tarea fácil, se complica cuando nos adentramos en el ámbito militar, habiendo podido constatar que no existe consenso ni postura doctrinal unánime respecto de varias cuestiones, como por ejemplo, en relación a la diligencia de entrada y registro por parte del mando militar, que en la práctica sigue suscitando multitud de dudas e inseguridad jurídica.

Las Fuerzas Armadas tienen constitucionalmente atribuidas la misión de garantizar la soberanía e independencia de España, defender su integridad territorial y el ordenamiento constitucional tal y como se dispone en el artículo $8 \mathrm{CE}$ y ello las dota de una singularidad que justifica determinadas restricciones en el ejercicio de algunos

\footnotetext{
${ }^{135}$ Vide. SSTC 292/2000, de 30 de noviembre; 70/2002, de 3 de abril y 83/2002, de 22 de abril.

${ }^{136}$ Según nuestra opinión, constituye un reflejo de cuanto acabamos de indicar, la previsión de la Instrucción Técnica 13/05 de la Inspección General de Ejército, en cuanto a los registros, disponiendo que cuando existan indicios o se haya cometido un delito o falta, previamente se requerirá el consentimiento del interesado y de no concurrir éste, será precisa, para proceder al registro, la correspondiente autorización judicial, poniéndose entretanto la oportuna vigilancia en el dormitorio.
} 
derechos constitucionales por parte de sus miembros, entre otros el derecho a la inviolabilidad del domicilio.

Tal y como se expuso al principio de este estudio, las Fuerzas Armadas tienen misiones vitales para el Estado, con el uso de la herramienta de la "violencia organizada", pero observamos que constitucionalmente no aparece explicitada la limitación de los derechos fundamentales para el cumplimiento de tales misiones, salvo algunos de carácter político. ${ }^{137}$

Hemos aludido a la "relación de sujeción especial" del militar como origen de la limitación del derecho fundamental a la intimidad e inviolabilidad del domicilio en el ámbito castrense y llegamos a la conclusión de que la misma justifica, por sí sola, la existencia de una jurisdicción propia, unos principios rectores que rigen la actividad diaria del militar, así como una legislación específica de la que quedan abstraídos el resto de ciudadanos.

Todo ello, bien es cierto, tiene su máximo exponente en los límites aludidos al derecho fundamental que nos ocupa. Ahora bien, siguiendo a nuestro Tribunal Constitucional, esas limitaciones, no son ni gratuitas ni arbitrarias.

No son arbitrarias, porque en todo caso han de venir reguladas por una Ley Orgánica, esto es, la Ley Orgánica 9/2011 de 27 de julio, de Derechos y Deberes de los miembros de las Fuerzas Armadas, que garantiza el respeto a un contenido mínimo del derecho fundamental, así como el que dichos límites sean adecuados y proporcionados a los fines que con ellos se pretenden alcanzar. Tampoco serán arbitrarios, en tanto en cuanto, quedan justificados por las misiones asignadas a las FAS en el referido artículo $8 \mathrm{CE}$.

Tras nuestro estudio, pues, ninguna duda ofrece el reconocimiento del derecho fundamental a la intimidad e inviolabilidad del domicilio en el ámbito castrense. Centrando aún más la cuestión de fondo, llegamos a la conclusión de que la inviolabilidad del domicilio, resulta ser un derecho que pretende garantizar el ámbito de privacidad de la persona dentro del espacio limitado que ésta elija, y tiene que caracterizarse, precisamente, por quedar exento e inmune a las agresiones o invasiones exteriores de otras personas o de la autoridad.

Responde a un derecho de la personalidad que impide la entrada y registro a un domicilio sin el consentimiento de su titular y sin previa autorización judicial, salvo en determinados supuestos excepcionales contemplados por la ley.

Un derecho fundamental del ciudadano cuya restricción, en cuanto supone una invasión de la zona de intimidad privada protegida por aquél, constituye un serio ataque a esferas de privacidad, que sólo puede ser acordado por resolución judicial.

No obstante lo anterior y aun cuando del régimen de vida de los acuartelamientos se trate, también es cierto, que nos encontramos ante un derecho fundamental que no gozará del carácter de absoluto, sino que puede ser objeto de restricciones o limitaciones por parte del legislador, eso sí, respetando siempre su contenido esencial.

La aludida Ley Orgánica de Derechos y Deberes de los miembros de las Fuerzas Armadas, reconoce el derecho a la inviolabilidad del domicilio del militar, intimidad e inviolabilidad que se contiene en el artículo $18 \mathrm{CE}$, y que resulta de aplicación a todos los ciudadanos, por lo que los miembros de los Ejércitos no constituyen una excepción.

${ }^{137}$ Sobre ésta cuestión, Vide. Díaz Alegría, M.: Ejército y Sociedad. Madrid: Alianza Editorial. Madrid. 1972. 
Ahora bien, si tras el estudio realizado, podemos afirmar con rotundidad que el militar tiene reconocido el derecho fundamental a la intimidad e inviolabilidad domiciliaria, también es cierto que, por razón de las especialidades a las que nos referimos en líneas precedentes, la cuestión se complica, por ejemplo, a la hora de delimitar el concepto de domicilio tanto desde el punto de vista jurídico como especialmente desde el punto de vista de su protección constitucional.

Aparentemente resultaba ser una cuestión debatida y sobre la que existía cierto consenso, pero la elaboración del trabajo y el estudio a fondo de la materia, nos ha demostrado que no es así, especialmente cuando descubrimos la diversidad de opciones que se le presentan al personal militar cuando de residencia o domicilio se trata.

De nuestra investigación resulta la evidencia de un amplio abanico de legislación y regulación reglamentaria, a su vez dispersa, respecto de los diferentes tipos de "domicilio" situados tanto dentro de los acuartelamientos como fuera de ellos cuando en este último caso de alguna manera quedan adscritos al Ministerio de Defensa. En la misma línea, cada Ejército tiene su propia normativa y define de manera diferente los distintos tipos de alojamiento lo cual, dificulta de manera manifiesta la unificación de criterios o conceptos. Así mismo, los distintos tipos de alojamiento; alojamientos logísticos, módulos de alojamiento, residencias militares, viviendas militares, pabellones de cargo, tiendas de campaña, etc. Todo ello, aconseja tanto la unificación de conceptos, como de criterios y régimen jurídico.

Nuestra postura al respecto aplicada al ámbito militar, es la mantenida por el TC en su jurisprudencia con carácter general, esto es, nos hallaremos ante una morada susceptible de protección constitucional, cuando con independencia de su ubicación, esto es, dentro o fuera de una instalación militar, en el mismo se pueda desarrollar y se desarrolle objetivamente vida íntima.

Por esto, consideramos que resulta ser irrelevante a los efectos de protección constitucional, que el habitáculo sea asignado por un mando o autoridad militar, que no pueda ser elegido por el usuario, que por su uso se pague un canon simbólico, que la titularidad corresponda al Estado o que existan limitaciones en cuanto al uso o desarrollo de actividades en el mismo.

La situación física, en nuestra opinión, también es irrelevante a los efectos que nos ocupan. No importa que se trate de un recinto ubicado en un lugar militar, en un buque de guerra, aeronave militar, zona de operaciones, etc., si objetivamente es apto para desarrollar vida íntima, sin las limitaciones de los usos y convenciones sociales, estaremos ante un domicilio, máxime cuando en los últimos tiempos, la crisis económica, las dificultades para acceder a una vivienda y la comodidad que supone residir prácticamente en el lugar de trabajo, hace de este tipo de alojamientos todo un reclamo que suele perdurar en el tiempo al poder desarrollar el usuario su vida privada en condiciones muy similares a como podría hacerlo fuera del acuartelamiento.

En base a estos razonamientos, llegamos a la conclusión de que tienen carácter de domicilio, las habitaciones de las residencias militares, los dormitorios situados en los alojamientos logísticos, los camarotes de los buques de guerra, viviendas militares o pabellones de cargo, cuando su uso es individual o compartido con la familia e incluso las tiendas de campaña si en ellas se reúnen unas condiciones básicas donde poder ejercitar una convivencia mínima. Y todo ello, además, con independencia de que la residencia sea estable o transitoria o el morador sea propietario o simplemente el poseedor. 
Esta conceptuación, resulta especialmente relevante a la hora de ejecutar actos procesales, tales como el que constituye la diligencia de entrada y registro, pues de tratarse de espacios protegidos por el derecho a la inviolabilidad del domicilio, deberá quedar revestida de las garantías tanto constitucional como procesalmente establecidas a la hora de acceder a este tipo de lugares, evitando así, en la medida de lo posible, la nulidad de pleno derecho tanto de la diligencia como de las pruebas que se pretendan conseguir con la materialización de la misma en virtud del artículo 11 de la LOPJ.

Bajo nuestro criterio queda claro que el mando militar es el responsable de todo cuanto acontece en la unidad, de su seguridad y régimen interior. Por eso, resultan prácticas las revistas e inspecciones ordenadas y efectuadas por el mismo, normalmente con la finalidad de salvaguardar ese orden, pues en otras ocasiones, lo que se pretende es intimidar o en su caso sancionar conductas que supongan infracción de las normas militares, delitos o infracciones disciplinarias, como puede ser por ejemplo, la introducción y tenencia de sustancias psicotrópicas en el buque, instalación o acuartelamiento militar. Pero nuestra consideración al respecto, exige la distinción de lo que es la inspección o revista, de la diligencia de entrada y registro; es decir, con la finalidad de mantener el buen orden dentro de la unidad, el mando militar, podrá inspeccionar o revisar instalaciones militares que no tengan la consideración de domicilio, podrá reconocerlas o examinarlas, pero esa inspección no lo legitimará a abrir cajones, armarios, etc.... allí ubicados, e insistimos, siempre y cuando no tengan la consideración de domicilio, pues si en base a la argumentación anteriormente expuesta, tienen la consideración de domicilio, nuestra opinión es que será preceptivo el consentimiento del morador y en su defecto autorización judicial.

Luego, a modo de corolario y al hilo de todo lo anteriormente expuesto, dando respuesta a otra de las preguntas que nos hacíamos al inicio de este trabajo, añadimos, que en nuestra opinión, los mandos militares no están legitimados para efectuar ni entradas ni registros en instalaciones militares que tengan consideración de domicilio. De ahí nuestro estudio y de ahí la necesidad de delimitar conceptualmente y jurídicamente el amplio abanico de posibilidades que los distintos espacios a los que nos hemos referido, brindan al militar a la hora de desarrollar su vida íntima, toda vez que de ese régimen jurídico pende la legitimación del mando en las habituales entradas y registros en las distintas dependencias militares, pues si de domicilio se tratare, ante la presunción o certeza de la existencia de indicios de la perpetración de delitos militares o infracciones disciplinarias, en defecto del consentimiento del titular del derecho fundamental a la inviolabilidad del domicilio, el mando militar carecerá de legitimación para practicar las mismas, debiendo requerir a tal fin, autorización del juez, en este caso, del juez togado militar.

\section{Bibliografía.}

Alonso de Antonio, A.L.: El derecho a la inviolabilidad domiciliaria en la Constitución española de 1978. Editorial Colex. Madrid. 1993.

Casado Burbano, P.:

- Iniciación al derecho constitucional militar. EDERSA. Madrid. 1986.

- «Visión Histórica del Derecho Penal Militar Español. Comentario al Capítulo I del Código penal Militar», en AA.VV. (coord. José Luis Rodríguez Villasante), Comentarios al Código Penal Militar. Editorial Civitas. Madrid. 1988.

Corcoy Bidasolo, M.: Derecho Penal, Parte Especial, doctrina y jurisprudencia con casos solucionados. Tomo I. Tirant lo Blanch. Valencia. 2011. 
Climent Duran, C.: La prueba penal. Tomo II, $2^{\mathrm{a}}$ ed. Tirant lo Blanch. Valencia. 2005.

Díaz Alegría, M.: Ejército y Sociedad. Madrid: Alianza Editorial. Madrid. 1972.

Diccionario Básico Jurídico. Editorial Comares, 4ª edición. Granada. 1994.

Embid Irujo, A.: La fidelidad de los funcionarios a la Constitución (un estudio de los Derechos alemán y español). INAP. Madrid. 1987.

Esquivias López-Cuervo, A; Joly Palomino F. y Martín Vicente M.: Comentarios a la Ley Disciplinaria Militar. Diario de Cádiz. Cádiz 1999.

Fernández Rodera, J.A.: «Límites al ejercicio de derechos cívicos en el ámbito castrense», Revista del Ejército, nº 525, octubre 1983.

Fernández Segado, F.:

- «El perfil diferencial de la escala de valores de la Institución Militar». Revista de Estudios Políticos n51, mayo-junio 1986.

- «La posición constitucional de las Fuerzas Armadas». Revista Española de Derecho Militar, $\mathrm{n}^{\circ}$ 67.1996.

Figueroa Navarro, M.C.: Entrada y registro en domicilio. Tecnos. Madrid. 1994.

Herrero de Miñón, M. en Diario de Sesiones del Congreso de los Diputados (Comisión de Asuntos Constitucionales) de 16 de mayo 1978.

Gallego Anabitarte, A.: «Las relaciones especiales de sujeción y el principio de legalidad de la Administración. Contribución a la teoría del Estado de Derecho», Revista de Administración Pública, $\mathrm{n}^{\circ}$ 34, año XII, enero-abril 1961 (reimpresión octubre 1972). Instituto de Estudios Políticos. Madrid.

García de Enterría, E y Fernández, Tomás-Ramón.: Curso de Derecho Administrativo (Tomo I y II). Editorial Cívitas. Madrid. 1990. 1985.

Garrido Falla, F.: Comentarios a la Constitución. Editorial Cívitas. Madrid.

Gimeno Sendra,V.: Los Derechos Fundamentales y su Protección Jurisdiccional. Editorial Colex. Madrid. 2007.

González- Trevijano, P.J.: La inviolabilidad del domicilio. Temas clave de la Constitución Española. Editorial Tecnos. Madrid. 1992.

Gómez Martínez, R.: Derechos fundamentales y condición militar. Editorial Civitas. Navarra. 2010. 2010.

Gómez Tomillo, M. (Dir.): Comentarios al Código Penal, Lex Nova. Valladolid.

López Benítez, M.: Naturaleza y presupuestos constitucionales de las relaciones de especial sujeción, prólogo de Luis Cosculluela Montaner. Editorial Cívitas. Madrid. 1994.

Luzón Cuesta, J.M.: La prueba en el proceso penal derivada de la entrada y registro en domicilio. Biblioteca Jurídica de bolsillo, $\mathrm{n}^{\circ}$ 43. Editorial Colex. Madrid.

Magro Servet, V.: «Casuística sobre el concepto penal de domicilio en la diligencia de entrada y registro», La Ley, fascículo 2002-2.

Matía Portilla, F.J.: El derecho fundamental a la inviolabilidad del domicilio. McGraw-Hill. Madrid. 1997.

Morenilla Rodríguez, J.M.: «El derecho al respeto de la vida privada en la jurisprudencia del TEDH». En la Jurisprudencia del TEDH. CGPJ. Madrid. 1993.

Moreno Catena, V.: «Garantía de los derechos fundamentales en la investigación penal». Revista del Poder Judicial. Justicia Penal. Núm. Especial II, marzo 1987. 
Navas Sánchez, M.M.: ¿Inviolabilidad o intimidad domiciliaria?. A propósito de la jurisprudencia constitucional sobre el derecho fundamental a la inviolabilidad del domicilio. Revista de Derecho Político nº 81, mayo- agosto. UNED. 2011.

Pascual Sarría, F.L.: «La entrada y registro en las instalaciones militares», Jornadas sobre jurisdicción militar. CGPJ. 2007.

Peñarrubia Iza, J.M.: Presupuestos constitucionales de la función militar. Centro de Estudios Políticos y Constitucionales. Madrid. 2000.

Queralt Jiménez, J.J.: Derecho Penal Español, Parte Especial. Atelier. Barcelona, 5a ed., 2008.

Queralt, J.J.; y Jiménez Quintana, E.: Manual de Policía Judicial, Ministerio de Justicia. Madrid. 1987.

Querol y Durán, F.: Principios de Derecho Militar Español (Vol. I). Editorial Naval. Madrid. 1948.

Sánchez Morón, M.: Derecho de la Función Pública. Editorial Tecnos. Madrid. 1997.

Trillo-Figueroa y Martínez-Conde, F.:

- «Las Fuerzas Armadas en la Constitución Española», Revista Española de Derecho Militar, $\mathrm{n}^{\circ}$ 38, 1979.

- «Las Fuerzas Armadas en la Constitución Española (Esbozo de una Constitución Institucional)», Revista de Estudios Políticos nº12. 1979.

Urbano Castrillo, E. y Torres Morato, M.A.: La prueba ilícita penal: estudio jurisprudencial, $3^{\circ}$ edición. Editorial Thomson. Pamplona. 2003. 